\title{
Evlat edinen ve koruyucu ailelerin bebek ve küçük çocuklarıyla ilgili eğitim ihtiyaçları
}

\section{Educational needs of adoptive and foster families regarding their infants and toddlers}

\author{
Makale Geçmişi \\ Geliş : 25 Mart 2021 \\ Düzeltme : 21 Haziran 2021 \\ Kabul : 30 Haziran 2021
}

\section{Makale Türü}

Arastruma Makalesi

\section{Article History}

Received : 25 March 2021

Revised :21 June 2021

Accepted : 30 June 2021

\section{Article Type}

Research Article

\author{
Neslihan Avc1 ${ }^{1}$, Berrin Somer Ölmez ${ }^{2}$, Müge Kunt ${ }^{3}$, Pelin Pekince ${ }^{4}$
}

Öz: Bu çalışmada evlat edinen ve koruyucu ailelerin özellikle erken müdahale uygulamalarında bebek ve küçük çocuklarıyla ilgili eğitim ihtiyaçlarını ve taleplerini belirlemek amaçlanmıştır. Nitel bir durum çalısması olan araştırmanın katılımcılarını, Ankara ilinde ikamet eden evlat edinen ve koruyucu aile olan 11 kişi (2'si çift, 2 baba, 9 anne) oluşturmaktadır. Katılımcılar uygun örnekleme tekniğinden yararlanılarak Ankara Aile, Çalışma ve Sosyal Hizmetler İl Müdürlüğü aracıllı̆ıyla belirlenmiştir. Veri toplama aracı olarak yarı yapılandırılmış görüş̧me soruları kullanılmıştır. Odak grup görüşmeleriyle elde edilen veriler, "Bebekliğe bakış, Bebekle ebeveyn arasındaki ilişkiye bakış, Bebeklik dönemiyle ilgili merak edilenler, Yeterlikler, yetersizlikler ve güçlükler, Bebeklik dönemiyle ilgili bilgilerin öğrenildiği kanallar, Verilecek eğitimin içeriğiyle ilgili öneriler” kategorileri altında toplanmıştır. Araştırma Ankara Kalkınma Ajansı tarafından desteklenmiş; Gazi Üniversitesi'nin yürütücülüğü, Ankara Aile, Çalışma ve Sosyal Hizmetler İl Müdürlügü’nün ortakllğı ile gerçekleşen Güvenli Bebekler Güvenli Yarınlar projesi kapsamında yapılmıştır.

Anahtar Kelimeler: Erken müdahale, Aile eğitimi, Evlat edinen aile, Koruyucu aile, Çocukluk anlayışı

Abstract: In this study, it was aimed to determine the educational needs and demands of adoptive and foster families regarding their infants and young children, especially in early intervention practices. The participants of the study, which is a qualitative case study, consist of 11 adoptive and foster families (2 fathers, 9 mothers, 2 of them are couples) residing in Ankara. Participants were determined through the Ankara Provincial Directorate of Family, Labor, and Social Services by applying the convenience sampling technique. Semi-structured interview questions were used as data collection tools. The data obtained through focus group interviews were collected under the categories of "Perspective on infancy, view of the relationship between baby and parent, curiosity about infancy, competencies, inadequacies, and difficulties, channels that learn about infancy, suggestions about the content of the training to be given". The research was supported by Ankara Development Agency; and it was carried out within the scope of Güvenli Bebekler Güvenli Yarınlar (The Safe Babies Safe Tomorrow) project, which was conducted by Gazi University in partnership with Ankara Provincial Directorate of Family, Labor and Social Services.

Keywords: Early intervention, Family education, Adoptive family, Foster family, Understanding of childhood

\section{SUMMARY}

\footnotetext{
Başlıca Yazar: Neslihan AVCI

*Bu makale, 11-14 Mayıs 2017 tarihleri arasında düzenlenen 9. Uluslararası Eğitim Araştırmalanı Kongresi'nde "sözlü bildiri” olarak sunulmuştur.

${ }^{1}$ Gazi Üniversitesi, Gazi Eğitim Fakültesi, Temel Eğitim Bölümü, navci@gazi.edu.tr, ORCID: https://orcid.org/0000-0001-7988-3923

${ }^{2}$ Gazi Üniversitesi, Gazi Eğitim Fakültesi, Temel Eğitim Bölümü, berrinsomer@gazi.edu.tr, ORCID: https://orcid.org/0000-0001-5235-5389

${ }^{3}$ Gazi Üniversitesi, Gazi Eğitim Fakültesi, Temel Eğitim Bölümü, mugekunt@gazi.edu.tr, ORCID: https://orcid.org/0000-0002-4603-8210

${ }^{4}$ Gazi Üniversitesi, Gazi Eğitim Fakültesi, Temel Eğitim Bölümü, pelinpekince@gazi.edu.tr, ORCID: https://orcid.org/0000-0002-3543-1981
} 


\section{Introduction}

Infancy is referred to the critical years for children to develop the foundations of child and parent interaction, a sense of trust, and adaptation to the world. In this period, parents who provide primary care for the child build a warm and loving relationship with the baby, resulting in the formation of a basic sense of trust in the baby, which refers to secure attachment. Accordingly, it is significant to meet children's needs, particularly in the first years of life. Parents' awareness of their baby's physiological, psychological, and world recognition needs and the perception of personal competence or inefficiency to meet these needs affect the parent-infant relationship's quality and the infant's development (Ainsworth et al., 1978; Bowlby, 2012a, 2012b; Gopnik, 2015; Montigny \& Lacharité, 2005; Perry \& Szalavitz, 2017). Self-determination theory expresses the basic psychological needs as autonomy, competence, and relatedness (Deci \& Ryan, 2000). The childhood environment mentioned concerning these needs directly affects development in childhood, childhood concepts, and services provided to children (Jenks, 2005).

The quality of the family environment in which children live is paramount for their healthy development. There are social service models such as adoption or foster family to protect children from various risk factors and develop in a good family environment for those who do not have the opportunities to live with their biological families for various reasons (Boyd-Webb, 2017; Tezel, Demirel \& Şahin-Kaya, 2018). It would be appropriate to determine adoptive/foster families' characteristics adequately and take steps considering these characteristics to work with them. The present study aims to determine the needs and requirements of adoptive and foster families concerning their infants' and young children's education, particularly in early intervention practices. This research has been conducted within the scope of the Safe Babies Safe Tomorrow project supported by Ankara Development Agency and executed by Gazi University collaborating with Ankara Provincial Directorate of Family, Labor, and Social Services.

\section{Method}

11 participants ( 2 fathers, 9 mothers, 2 of them are couples) from adopted and foster families residing in Ankara province participated in the present qualitative case study. The participants were recruited applying the convenience sampling technique through Ankara Provincial Directorate of Family, Labor, and Social Services. The data were obtained by administering a focus group interview. Semi-structured interview questions were used as a data collection tool. Interview questions include the positive and negative feelings that families attribute to the infancy period, their definition of the relationship between the baby and the mother/father, problems they experience, and supports they need as solutions concerning these problems. The content analysis method was used to analyze the interview findings. Themes, categories, and codes were extracted after reading all the data, and then the data were interpreted. The interviews were conducted on a voluntary basis and informed consent was obtained from the participants.

\section{Results}


It has been observed that adoptive and foster families have understanding regarding infancy that includes various emotions from glorified child understanding to insufficient child understanding and feelings such as responsibility or happiness in their inner selves. Families have described their relationship with their children as both positive feelings, for instance, affection and happiness, and challenging feelings such as responsibility and exhaustion. It was recognized that families who had shown curiosity about the infancy period wanted to learn concepts related to their children's physiological needs and the topics of child psychology. In terms of competencies, inadequacies, and difficulties, findings demonstrate that the adoptive and foster families felt adequate in showing affection. In addition, it was determined that adoptive and foster families felt inadequate in issues such as stubbornness or convincing the baby, crying, sleeping patterns, deciding on the appropriate education method, and what can be done about unwanted behaviors. Besides, they experience predicaments in being accepted in their social ambiances and receiving environmental support. It was determined that the adoptive and foster families learn information concerning their infants and infancy period from various sources such as professionals, both their own experiences and those around and the internet. The families had suggested receiving training on issues like explaining the adoption to the adopted/foster child, community acceptance of the child, achievement or unfulfillment of secure attachment, and professional support concerning the children's developmental stages. Families also consider that professionals working in related organizations should receive in-service training, and collaboration with relevant ministries is required.

\section{Conclusion and Discussion}

The perspective regarding the infancy period of the adoptive and foster families with children between 0 24 months of age is paramount as it will constitute the educational premises provided to them. The families' viewpoint regarding infancy understanding was categorized under three sub-categories: "the glorified child, the insufficient child, and the responses relevant to the parents' internal processes." It is significant to consider the processes of being adopted and foster a family while recognizing the participants' characteristics. During evaluating this circumstance, notably in the light of the answers provided by the families in the sub-category of the glorified child such as "love, infinite love, princess...", the first thing that comes to mind is the duration of the families' uniting with their children and the intensity of the emotions they experience during this period. The responses concerning the sub-category of the glorified child and giving more meaning to a baby are acknowledged to be the reflections of families' different expectations during the readiness process. Correspondingly, families refer to insufficient children as "need to be protected, require constant care, innocent, pure ..." emphasizing the underdeveloped and insufficiency of infancy may also derive from these processes. It is also evident that families who refer to infancy as innocent and pure consider their children as passive subjects of their own lives, not only developmentally but also sociologically, and recognize them as inadequate individuals who need adult support. However, the selfdetermination theory (Deci \& Ryan, 2000) emphasized that each individual has an innate tendency for development, and this temperament emerges with the support of the social environment. The support mentioned here must be perceived by considering children's psychological needs (Deci \& Ryan, 2000), such 
as autonomy and competence. The sub-category responses regarding the parents' internal processes can be described as the emotions a baby stimulates in their inner selves, such as "responsibility, happiness, devotion..." feelings that motivate them to become parents.

The aspects that families feel inquisitive about regarding the infancy period are categorized in sub-categories of physiological needs and child psychology. Physiological needs refer to the infant's height, weight characteristics, daily routines such as nutrition and sleep. Child psychology includes how and when to tell about the adoption and fostering and social environment impacts. Uninformed of how to explain this situation to the child may cause it to be shared late, and sometimes it may lead to obscuring. One of the most crucial concerns of families is the fear that the child will learn the truth from an outsider. Another concern is the social environment's negative attitude towards the child and family. Given that, families may tend to hide the fact from the social environment.

When families were asked about the issues they feel adequate about, they addressed emotions like "love," and similarly to biological families, they feel inadequate in developmental processes, daily routines, and preventing unwanted behaviors. It is crucial for families to know the professionals who they can consult with regarding these issues. Nevertheless, families emphasized that they need support in this regard, even though they consider professionals such as doctors and institution professionals and people in their social ambiance as sources related to infancy.

The recommendations of the families at the micro-level regarding education are related to the achievement or unfulfillment of secure attachment, the acceptance of the child to the social environment, and how to receive professional support regarding developmental periods. Macro-level suggestions include that professionals working with children should be well-informed about the dynamics of adopted or foster children through in-service training.

\section{GİRİ̧}


Bebeklik dönemi; çocuk ve ebeveyn arasındaki etkileşimin temellerinin atıldığı, güven duygusunun geliştiği ve çocuğun dünyaya uyum sağlama yetileriyle gelişiminde önemli bir hız kazandığı kritik yıllar olarak tanımlanmaktadır. Bu dönemde çocuklarının birincil bakımlarını sağlayan ebeveynlerin rolü, sağlıklı gelişimin ve güvenli bağlanmanın gerçekleşmesinde çok önemli bir yere sahiptir. Çocuk için yaşamın ilk yıllarında güven duyulacak bir figürün olması bağlanma konusunda ilk basamak olarak düşünülebilir. Devam eden basamaklar için bağlanma kuramı, bakım verenin bebeğin ihtiyaçlarına istikrarlı bir şekilde duyarlılık göstermesi gerektiğini vurgulamaktadır. Duyarlılık, bebekten gelen ağlama, göz teması ve ses çıkarma gibi davranışsal sinyalleri zamanında okumayı ve gerekli şekilde yanıt vermeyi içermektedir (Bowlby, 2012b; Gopnik, 2015; Greenspan ve Lewis, 2006; Perry ve Szalavitz 2017; Trawick Swith, 2013).

Ebeveynin bebeğiyle sıcak ve sevgi dolu bir ilisski kurması sonucunda bebekte temel güven duygusunun oluşması ve bebeğin dünyayı güvenle keşfetme girişimleri, güvenli bağlanmayı ifade etmektedir (Ainsworth, Blehar, Waters ve Wall, 1978; Bowlby, 2012a). Bu nedenle özellikle yaşamın ilk yıllarında çocukların gereksinimlerinin karşılanması ve desteklenmesi önemli görülmektedir (Erkan, 2013). Bir annenin ya da babanın bebeğinin fizyolojik (temel bakım, beslenme, uyku, sağlık vb.), psikolojik ve dünyayı tanıma ihtiyaçları konusundaki farkındalığı, bu ihtiyaçları karşılama konusundaki kişisel yeterlilik ya da yetersizlik algısı (Montigny ve Lacharité, 2004) ebeveyn-bebek ilişkisinin kalitesini ve bebeğin gelişimini etkilemektedir (Gelkopf ve Jabotaro, 2013). Diğer taraftan biyolojik faktörler de düşünüldüğünde çocuklar stres ve sıkıntılara karşı genetik olarak daha fazla veya daha az dayanıklı olabilmektedirler. Fakat bu dayanıklılığın çocuğun ilk ve temel ilişkileri bağlamında artabileceği veya azalabileceği vurgulanmaktadır (Perry ve Szalavitz 2017). Kısacası erken duygusal ilişkilerin, bu deneyimlerin yapısına bağlı olarak gelişen belirli beyin fonksiyonlarını etkileyen ana unsur olduğu anlaşılmaktadır. Bebeğin bakımını sağlayan kişiden alınan hassas ve rahatlatıcı cevaplar optimum beyin gelişimini desteklemektedir (Masterson, 2013; Perry ve Szalavitz 2017; Van der Kolk; 2020). Dolayısıyla ebeveyn davranışları temel ilişkilerin oluşumunda kritik bir yere sahiptir. Ayrıca başarılı ebeveynlik, gelecek neslin ruh sağlığı için kilit bir öneme sahiptir. Bu nedenle ebeveynliğin hem doğasını hem de ebeveynliği iyi veya kötü yönde etkileyen sosyal ve psikolojik şartlarla ilgili hemen hemen her şeyin bilinmesinde yarar vardır (Bowlby, 2012b).

Ebeveynliğin tüm yönleriyle bilinmesinin yanı sıra ebeveynlerin çocuklarını tanıma konusunda da çocuğun doğasına inanc1 yansıtan bir çocukluk anlayışı benimsemeleri önemli görülmektedir. $\mathrm{Bu}$ noktada bireyin evrensel ve psikolojik ihtiyaçlar ile birlikte gelişmek için doğuştan gelen bir eğilimi olduğu ve bu eğilimin sosyal çevrenin desteğiyle ortaya çıtı̆̆ını açıklayan öz belirleme kuramına dikkat çekmek gerekmektedir. Ebeveyn bebek etkileşiminde bebeklerin ve küçük çocukların ihtiyaçlarının zamanında ve yeterli bir şekilde karşılanması önemli bir husustur. Öz belirleme 
kuramına göre temel psikolojik ihtiyaçlar; özerklik, yetkinlik ve ilişkisellik (sosyal ilişki ihtiyacı) olarak ifade edilmektedir. Özerklik; kişinin bireysel kararlar alabilmesine, yetkinlik; çevresiyle başa çıkabilme konusunda kendine olan inancına, ilişkisellik ise; doyum veren sosyal etkileşimine karşıllık gelmektedir (Deci ve Ryan, 2000). Bu kuramda belirtilen gereksinimlerin karşılanmasında ise çocukluğun geçtiği ortamın fiziksel ve psikolojik özelliklerinin, çocukluk dönemindeki gelişimi etkilemesinin yanı sıra yetişkinlerin çocukluk anlayışını da etkilediği vurgulanmaktadır (Jenks, 2005). Çocukların gereksinimlerinin ve yetişkinlerin çocukluk anlayışlarının bilinmesi çocuklara sağlanacak uygulamaları doğrudan etkileyeceği için önemli görülmektedir. Bu noktada kuramsal boyutların dışında çocukluk yaklaşımlarının kategorilere ayrılmasını sağlayarak özellikle çocuklarla ilgili uygulamalara yol gösterici olacak çocukluk tipolojilerinin olduğunu bilmek gerekmektedir (Avc1, 2019; Haring, Sorin ve Caltabiano, 2019; Sorin, 2005). Bu tipolojiler arasında bütüncül bir bakış açısı sunan Sorin'in (2005) “on imaj” yaklaşımı dikkat çekmektedir. Sorin’in on imajı yetişkinlerin çocuğu; bakım ve korunmaya ihtiyaç duyan aciz ve saf varlıklar olarak gören masum çocuk imajından, yetkin ve kendi yaşamının etkin öznesi olarak gördükleri katılımcı çocuk imajına kadar farklı bakış açılarını kategorilendirerek ortaya koyan bir yaklaşımı içermektedir. Yetişkinlerin katılımcı çocuk imajını benimsemeleri hem çocukların gelişimleri hem de ebeveyn-çocuk etkileşiminin sağlıklı olabilmesi için önemli olan başka bir noktadır.

Tüm bu açıklamalar, çocukların bir bütün olarak gelişimlerinin sağlıklı olabilmesi için yaşadıkları aile ortamının ne kadar önemli olduğunu ortaya çıkarmaktadır. Çeşitli nedenlerle biyolojik ailesi yanında büyüme olanağı olmayan çocukların, gelişimleri açısından kurum bakımından daha sağlıklı olan bir aile ortamına yasalarla belirlenen kurallar dahilinde alınması, evlat edinme ya da koruyucu ailelik gibi sosyal hizmet modellerini ifade etmektedir. Bu modellerin ortak amacı, çocuğun çeşitli risk etmenlerinden korunması ve gelişimini bir aile ortamında sürdürmesidir (Boyd-Webb, 2017; Tezel, Demirel ve Şahin-Kaya, 2018). Bu amaçla çocukla çalışan uzmanların odak noktası, bir yanda yeni bir aile ve çevreye alışma sürecinde olan bir çocuk, diğer yanda ise daha önce nasıl yetiştirildiğine tanık olmadıkları bir çocuğun her türlü özelliğini kabul etme motivasyonuna sahip ebeveynlerdir (Chakawa vd. 2020). Bu tür ailelerle çalışmak için onların özelliklerini iyi tespit etmek ve bu yönde adımlar atmak yerinde olacaktır.

Literatür incelemesi sonucu Türkiye'de ve dünyada evlat edinen / koruyucu aile olan ebeveynlerin; evlat edinme konusundaki motivasyonları (Tezel, Demirel ve Şahin-Kaya, 2018), biyolojik ebeveynler ile çocuk yetiştirme stilleri, bağlanma süreçleri ve çocuklarının duygusal ve davranışsal problemleri açısından karşılaştırılması (Altınoğlu-Dikmeer, Erol ve Gençöz, 2014), aile yapısı ve kişilerarası ilişkiler bağlamında yaşanan değişimler (Erdugan, 2019), evlat edinme süreçlerinde çocuğun bağlı olduğu kurumla ilgili yaşanan sorunlar (Chanmugam vd. 2017) ve bu kurumlar 
hakkındaki aile görüşleri (LaBrenz vd. 2020), evlat edinilen çocukların aile ortamına uyumlarına dair algıları (Martin, Kelly ve Towner-Thyrum, 1999) gibi konuları ele alan çalışmalara rastlanmaktadır. Durum tespitinin yanında ailelerin çocuk yetiştirme konusundaki ihtiyaçlarının neler olduğu hakkında bilgi edinmek, yapılacak müdahale uygulamalarına sşık tutacaktır.

Ebeveynlik ihtiyaçları ele alındığında, öncelikle anne ve babanın fikirlerini, kendi aile yapıları içindeki değerlerini ve kültürel özelliklerini tespit etmek yerinde olacaktır. Toplumun ya da yetişkinlerin çocuğa ve çocukluğa bakış açıları; ebeveynlik stillerini, çocuğa atfedilen özellikleri, onlarla kurulan iletissim sırasındaki tutumları, beklentileri ve onlara tanınan hakları belirlemektedir (Tan, 1989). Günümüzde çocuklar ve ebeveynlerini hedef alan eğitim programlarının, çocukluk anlayışına yönelik iyileştirici ilkeler belirlemesi, söz konusu programların etkililiğini artıracaktır. Evlat edinilen ve koruyucu aile olunan çocuğa bakış açısı ise evlat edinilme durumunun çocuk ile paylaşılması, çocuğun mahremiyeti, sosyal çevredeki konumu ve kabulü gibi özel konuları da kapsamaktadır. Evlat edinen ailelerin bu tür konularda rehberliğe ihtiyacı vardır ve genellikle çocuklarıyla ilgili sürecin “normal, olması gerektiği gibi” ilerleyip ilerlemediğini merak etmektedirler. Araştırmalara göre evlat edinilen ve biyolojik ailesiyle yaşayan bebeklerin ebeveynleriyle olan bağlanma ilişkisinde çok az farklılık olmaktadır (Santrock, 2015). Kurum bakımından koruyucu ailelik ya da evlat edinilme yoluyla alınan bebeklerin bilişsel gelişimlerinde ise evlat edinilmeyi takip eden iki ila altı aylık süre içinde iyileşme olduğu tespit edilmiştir (Van den Dries vd. 2010). Ancak evlat edinilme sürecinin başlangıcından itibaren bebeğin yaşı, gelişimsel özellikleri ve sağlık durumu, biyolojik ailesiyle olan öyküsü, yeni sosyal çevresi tarafindan kabulü, yukarıda bahsedilen sonuçları etkileyebilmekte; bu durum ebeveyn-bebek çifti arasındaki kabul ve uyum sürecine de yansıyabilmektedir. Bu bakış açısıyla evlat edinen/koruyucu olan ailelerin erken müdahale kapsamında öncelikli bir grup olması, bebekleriyle etkileşimlerini artırmanın ve bağlanma davranışlarını desteklemenin önemini ortaya çıkarmaktadır. Ebeveynlerin bebek bakımı ve gelişimine dair tüm bilgi ihtiyacı, çocuklarla çalışan uzman bir ekip desteği ve kapsamlı bir eğitim programı ile daha anlamlı bir şekilde karşılanabilir. Evlat edinen ve koruyucu ailelerin özellikle erken müdahale uygulamalarında bebek ve küçük çocuklarıyla ilgili eğitim ihtiyaçlarını ve taleplerini belirlemek bu araştırmanın temel problemidir.

Ailenin eğitim ihtiyacı önemli bir konudur, çocuklarını destekleyici ebeveynlik için düzenli olarak ihtiyaçlarının belirlenerek desteklenmeleri gerekir. Evlat edinen ve koruyucu aileler ise bu konuda göz ardı edilen bir özel ihtiyaç grubudur. Duruma özgü olarak farklılaşabilecek ihtiyaçlarının ortaya konulması müdahale hizmetlerinin oluşturulabilmesi açısından önem taşımaktadır. Ülkemizde evlat edinen ve koruyucu ailelerinin ebeveynlik becerileri konusundaki ihtiyaçlarına yönelik çalşmalar oldukça sınırlı kalmıştır (Avcı, Ü. E., 2019; Tezel, Demirel ve Şahin-Kaya, 2018; Yıldırımalp ve Hız, 
2020). Araştırma Ankara Kalkınma Ajansı tarafindan desteklenmiş; Gazi Üniversitesi'nin yürütücülüğü, Ankara Aile, Çalışma ve Sosyal Hizmetler İl Müdürlüğü’nün ortakllğı ile gerçekleşen Güvenli Bebekler Güvenli Yarınlar projesinin ihtiyaç analizi aşamasında gerçekleștirilmiştir.

\section{YÖNTEM}

\section{Araştırma Modeli}

$\mathrm{Bu}$ çalışma; nitel araştırma desenlerinden durum çalışması türünde gerçekleştirilmiştir. Durum çalışması; özellikle değerlendirme süreçleri gibi birçok alanda kullanılmaktadır. Araştırmacının bir durumu; birey, kurum veya gruplarda belirli bir zaman süresince derinlemesine analiz ettiği bir araştırma desenidir (Creswell, 2014, s. 14; Glesne, 2015, s. 380; Yin, 2017, s. 4).

\section{Çalışma grubu}

Araştırmanın katılımcıları Ankara Aile, Çalışma ve Sosyal Hizmetler İl Müdürlüğü tarafindan davet edilen ve çalışmaya gönüllü kişilerin katılımıyla uygun örnekleme (Christensen, Johnson \& Turner, 2015, s. 172; Merriam, 2015, s. 77-78; Patton, 2014, s. 241) yoluyla belirlenmiştir. Uygun örneklemeye göre katılımcılar gönüllü olarak ve kolaylıkla çalışmaya dahil olabilecek kişiler arasından belirlenmektedir. Ayrıca bu teknik araştırmacılar açısından da çaba ve zaman gibi kaynaklar açısından tasarruf sağlayan bir örnekleme türüdür (Christensen, Johnson \& Turner, 2015, s. 172; Patton, 2014, s. 241). Bu amaçla belirlenen katılımcılar; Ankara ilinde ikamet eden evlat edinen ve koruyucu aile olan 11 kişiden (2'si çift, 2 baba, 9 anne) oluşmaktadır.

\section{Verilerin Toplanmas1}

Veriler ailelerle yapılan odak grup görüşmeleri yoluyla toplanmıştır. Odak grup görüşmeleri, küçük gruplarla belirli bir konu üzerinde hislerin, düşüncelerin ve deneyimlerin paylaşılabildiği bir görüşme yöntemidir (Johnson ve Christensen, 2014, s. 204). Bu çalışmada da görüşmeler ikinci ve üçüncü araştırmacıların bulunduğu tek bir oturumda gerçekleştirilmiştir. Diğer veri toplama yöntemlerinde olduğu gibi odak grup görüşmelerinde de birtakım sınırlılıklar olabilmektedir. Bazı katılımcılar; düşüncelerinin azınlıkta olduğunu fark etme, olumsuz tepki alma olasıllğ̆1 gibi nedenlerle kendilerini sözel olarak ifade etme eğiliminde olmayabilirler (Christensen, Johnson ve Turner, 2015, s. 60; Merriam, 2015, s. 92; Patton, 2014, s. 387). Bu araştırmada görüşmeler sırasında tüm katılımcıların kendilerini ifade etmeleri için firsat verilmesi ve yeterli süre tanınması gibi önlemler alınmasına rağmen özellikle belirli katılımcıların, görüşlerini paylaşma konusunda daha çok ön plana çıkması, bir sinırlılık olarak ele alınabilir. 
Odak grup görüşmelerinde yarı yapılandırılmış görüşme soruları kullanılmıştır. Görüşme sorularından ilk ikisi katılımcıları rahatlatarak motive etmek ve iletişimi genişletmek amacıyla "buz kırıcı" soru niteliğinde hazırlanmıştır (Chlup \& Collins, 2010; Kilanowski, 2012). Buz kırıcı soruların yanıtlanı katılımcılardan, görüşlerini bir kâğgda yazarak ifade etmeleri yöntemiyle toplanmıştır. Buz kırıcı sorulardan ilki katılımcıların bebeklik dönemine atfettikleri olumlu ve olumsuz duygularını, ikincisi de bebek ile anne/baba arasındaki ilişkiyi nasıl tanımladıklarını içermektedir. Katılımcılara bebeklik dönemiyle ilgili duygu ve düşüncelerini yansıtıcı soruların, görüşmenin başında yöneltilmesiyle; onların bebeklik dönemine ilişkin bakış açılarını belirmek amaçlanmıştır. Ayrıca katılımcılara yönelik hazırlanacak eğitim programlarının felsefesini ve içeriğini oluşturmak için katılımcıların çocukluk anlayışlarının ortaya konulması önemli görülmektedir.

Buz kırıcı soruların dışındaki görüşme soruları; katılımcıların bebeklik dönemiyle ilgili merak ettikleri konular, kendilerini yeterli-yetersiz hissettikleri konular, bebeklik dönemiyle ilgili bilgileri edinme yolları ve eğitime yönelik önerileri resmetmeye yöneliktir.

\section{Verilerin Analizi}

Odak grup görüşmeleri tamamlandıktan sonra ses kayıtları hiçbir değişiklik yapılmadan görüşmeciler tarafindan yazıya dökülmüştür. Elde edilen veriler içerik analizi ile çözümlenmiş, kategori, kod ve alt kategoriler belirlenmiştir. İçerik analizi, araştırmacının bir iletişim kaynağındaki içeriği açığa çıkarması yoluyla içeriğin ayrıntılı bir şekilde incelenmesine ve keşfedilmesine olanak sağlar (Neuman, 2010, s. 466). Verilerin doğrudan incelenmesiyle araştırmacılar tarafindan elde edilen kategori ve kodlara tümevarımsal kodlar adı verilmektedir. Nitel araştırmaların doğası gereği kod ve kategorilerin oluşturulması sürecinde tümevarım yöntemi sıklıkla kullanılmaktadır (Johnson ve Christensen, 2014, s. 525). Bu çalışmada da kod ve kategori oluşturulurken tümevarım yöntemi kullanılmıştır. Nitel araştırmalarda etik ilkeler dahilinde geçerli ve güvenilir veriler üretme kaygısı vardır. Bu amaçla araştırmacılar geçerlik ve güvenirlik için çeşitli önlemler almışlardır. Bunlardan biri, birden fazla araştırmacının veri analiz sürecinde yer alması ve verileri birbirinden bağımsız olarak analiz ettikten sonra elde ettikleri bulguları karşılaştırmasıdır. Bu karşılaştırmaya araştırmac1/kodlayıc1 üçgenlemesi denir ve geçerlik güvenirliğin sağlanmasındaki temel prensiplerden biridir (Merriam, 2015, s. 203-207). Bu amaçla veriler ikinci ve dördüncü araştırmacı tarafından bağımsız olarak değerlendirilmiştir. Görüş ayrıllı̆̆1 olan noktalarda birinci yazarın görüşlerine başvurulmuştur. Uzlaşma toplantısının sonucunda çıkan sonuçlar Güvenirlik = [Görüş Birliği / (Görüş Birliği + Görüss Ayr1lı̆ğ)]/100 formülü (Miles ve Huberman, 2015, s. 64) kullanılarak hesaplanmıştır. Yapılan güvenirlik çalışmasının sonucunda araştırmanın genel güvenirliği \%92 olarak saptanmıştır. Uzlaşma toplantısının sonucunda 8 kategori belirlenmiştir. Bu 
kategoriler; "Bebekliğe bakış, Bebekle ebeveyn arasındaki ilişkiye bakış, Bebeklik dönemiyle ilgili merak edilenler, Yeterlilikler, yetersizlikler ve güçlükler, Bebeklik dönemiyle ilgili bilgilerin öğrenildiği kanallar, Eğitimle ilgili öneriler” şeklindedir.

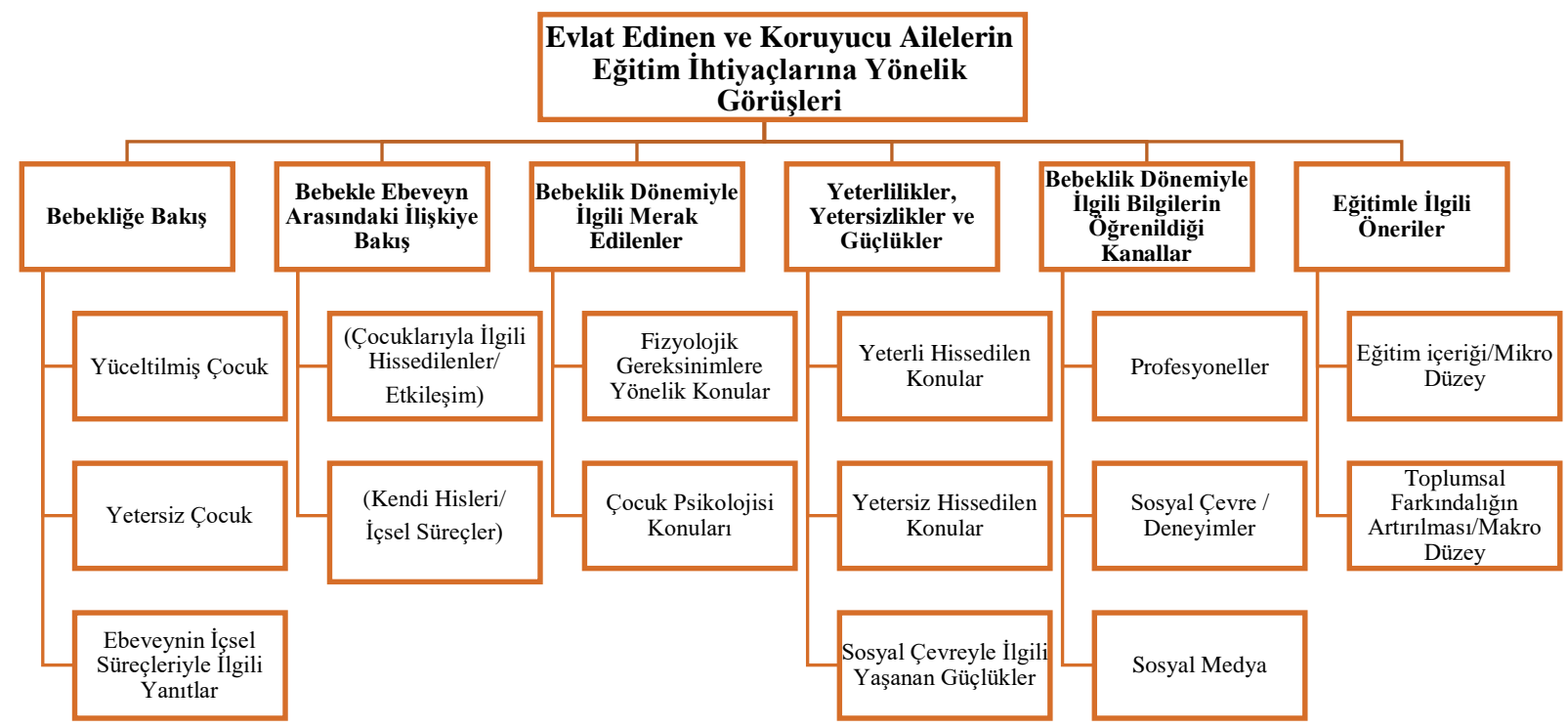

Şekil 1. Evlat Edinen ve Koruyucu Ailelerin Eğitim İhtiyaçlarına Yönelik Görüşleri

\section{Araştırmada Dikkat Edilen Etik İlkeler}

Araştırmaların veri toplama ve analiz süreçlerinde dikkat edilmesi gereken etik ilkeler bulunmaktadır. Etik ilkeler gerekli izinlerin alınması, araştırmaya katılma sürecinde katılımcılarının onamlarının alınması ve kişisel verilerinin korunmasını esas alır (Creswell, 2014, s. 95-97). Bu amaçla araştırmada; katılımcılar gönüllülük ilkesi doğrultusunda seçilmiştir. Görüşmelerden önce katılımcılardan aydınlatılmış onam alınmıştır. Görüşmeler sırasında katılımcılardan cevaplarının ses kaydının alınabilmesi için de katılımcılar bilgilendirilerek izin alınmıştır. Çalışmaya katılan kişilerin isimleri değiştirilerek rumuzlar konulmuştur ve çalışmanın geri kalanında cevapları bu rumuzlarla iletilecektir. Rumuzlar; İlke, Fulya, Erkan, Nida, Dilber, Gülay, Damla, Derya, Ali, Senem, Meltem olarak belirlenmiştir.

\section{BULGULAR}

Bu çalışmada, evlat edinen ve koruyucu ailelerle gerçekleştirilen görüşmeler sonucunda ailelerin bebek ve küçük çocuklarıyla ilgili eğitim ihtiyaçlarını belirlemek amaçlanmıştır. Görüşmelerden elde 
edilen bilgiler ışığında eğitim ihtiyaçlarına yönelik; "Bebekliğe bakış, Bebekle ebeveyn arasındaki ilişkiye bakış, Bebeklik dönemiyle ilgili merak edilenler, Yeterlilikler, yetersizlikler ve güçlükler, Bebeklik dönemiyle ilgili bilgilerin öğrenildiği kanallar ve Eğitimle ilgili öneriler” başlıklı kategoriler oluşturulmuştur. Bulgular bu kategorilere göre yorumlanmıştır.

\section{Bebekliğe Bakış Kategorisi}

Evlat edinen ve koruyucu ailelerin bebekliğe bakışlarına ilişkin yanıtları incelendiğinde görüşleri; bebekliğe bakış kategorisinin altında "yüceltilmiş çocuk, yetersiz, cocuk" ve "ebeveynin içsel süreçleriyle ilgili yantlar” olmak üzere üç alt kategoride toplanarak ilgili kodlarılla birlikte Tablo 2'de sunulmuştur.

Tablo 2. Bebekliğe bakış

\begin{tabular}{|c|c|c|}
\hline Kategori & $\begin{array}{c}\text { Alt } \\
\text { Kategoriler }\end{array}$ & Kodlar \\
\hline \multirow{3}{*}{$\begin{array}{l}\text { Bebekliğe } \\
\text { Bakış }\end{array}$} & $\begin{array}{l}\text { Yüceltilmiş } \\
\text { Çocuk }\end{array}$ & Aşk, sonsuz sevgi, tatlı, minnoş, sevimli, prenses \\
\hline & $\begin{array}{l}\text { Yetersiz } \\
\text { Çocuk }\end{array}$ & $\begin{array}{l}\text { Korunmaya muhtaç, sürekli bakım gerektiren, eğitilmesi gereken küçük insan, } \\
\text { yaramaz, saf, masum, melek }\end{array}$ \\
\hline & $\begin{array}{l}\text { Ebeveynin } \\
\text { İçsel } \\
\text { Süreçleriyle } \\
\text { İlgili Yanıtlar }\end{array}$ & $\begin{array}{l}\text { Sorumluluk, yorgunluk, evlat, koruma isteği, sabır, ilgilenmek, huzur, } \\
\text { mutluluk, heyecan, coşku, öncelik, bağlllık, değer, can, güven, nefes }\end{array}$ \\
\hline
\end{tabular}

Katılımcıların bebekliği; bir taraftan "aşk, sonsuz sevgi, tatl, minnoș, sevimli ve prenses" gibi çocukla ilgili olması gerekenden fazla olumlu özellikleri niteleyen ve abartılmış duyguları içeren sıfatlarla tanımladıkları görülmüştür. Diğer taraftan katılımcıların "korunmaya mubtaç, sürekli bakım gerektiren, eğitilmesi gereken küu̧ük insan, yaramaz, saf, masum ve melek" gibi çocukları yetişkin desteğine muhtaç ve gelişmemiş olarak gören yetersizlikleri içeren sıfatları da ifade ettikleri ortaya çıkmıştır. Ayrıca ebeveynlerin, kendi içsel süreçleriyle ilgili yanıtlar alt kategorisinde de; "sorumluluk, yorgunluk, evlat, koruma isteği, sabır, ilgilenmek, buzur, mutluluk, heyecan, coşku, öncelik, bağhllke, değer, can, güven ve nefes" gibi çocuklarını düşündükleri zaman çocuklarının kendi iç dünyalarında uyandırdığı duyguları tanımladığ1 görülmüştür.

\section{Bebekle Ebeveyn Arasındaki İlişkiye Bakış Kategorisi}

Katılımcıların bebek ebeveyn ilişkisine bakışlarına ilişkin yanıtları incelendiğinde; bebekle ebeveyn arasındaki ilişkiye bakış kategorisi "Çocuklaryla ilgili hissedilenler/Etkileşim ve Kendi hisleri/İcsel süreçler" olmak üzere iki alt kategoriye ayrılmıştır. Alt kategoriler ve kodlar Tablo 3'de yer almaktadır. 
Tablo 3. Bebekle ebeveyn arasındaki ilişkiye bakış

\begin{tabular}{|c|c|c|}
\hline Kategori & Alt Kategoriler & Kodlar \\
\hline $\begin{array}{l}\text { Bebekle } \\
\text { Ebeveyn }\end{array}$ & $\begin{array}{l}\text { Çocuklarıyla İlgili } \\
\text { Hissedilenler/Etkileșim }\end{array}$ & Assk, Sevgi, Oyun, Bağ \\
\hline $\begin{array}{l}\text { Arasındaki } \\
\text { İlişkiye } \\
\text { Bakış }\end{array}$ & Kendi Hisleri/İçsel Süreçler & $\begin{array}{l}\text { Şaşkınlık, Acemilik, Yorgunluk, Baş başa kalınca } \\
\text { tereddüt/yetersizlik, Özlem, Mutluluk, Heyecan, Bağlılık, Güven, } \\
\text { Huzur }\end{array}$ \\
\hline
\end{tabular}

Katılımcılar, bebekle ebeveyn arasındaki ilişkiye yönelik görüşlerini aşk, sevgi, özlem gibi kelimeleri içeren ifadelerle belirtmişlerdir. Örneğin; katılımcılardan Damla "Uykudayken bile özlemek" olarak duygusunu dile getirmiş, bu ifade özlem kodunun içinde değerlendirilmiştir. Meltem ise "Kavusma anındaki mutluluk." olarak duygusunu açılamış bu duygusu da mutluluk kodunda yer almıştır. İfadelerden "Aile olmak", "Etle kemik gibi bir bağ", "İki farkh bedende tek can olmak" cümleleri de (Çocuklarıyla ilgili hissedilenler/Etkileşim) alt kategorisinde yer alan bağ kodunda, "Her gün vakit geçirmek"” ise bağlllık kodunda değerlendirilmiştir.

\section{Bebeklik Dönemiyle İlgili Merak Edilenler}

Evlat edinen ve koruyucu ailelerin eğitim ihtiyaçlarını belirleyebilmek için öncelikle bebeklik dönemiyle ilgili merak ettikleri konular sorulmuştur. Katılımcıların yanıtları, Tablo 4'te bebeklik dönemiyle ilgili merak edilenler kategorisi içinde yer alan "Figyolojik Gereksinimlere Yönelik Konular ve Cocuk Psikolojisi Konularn” alt kategorileri ve kodlarla sunulmuştur.

Tablo 4. Bebeklik dönemiyle ilgili merak edilenler

\begin{tabular}{cll}
\hline Kategori & Alt Kategoriler & \multicolumn{1}{c}{ Kodlar } \\
\hline & & $\bullet$ Uyku \\
Febeklik & Fizyolojik Gereksinimlere & $\bullet$ Beslenme \\
Dönemiyle & Yönelik Konular & $\bullet$ Gelişimsel özellikler \\
İlgili Merak & & $\bullet$ Temel bakım (normal gelişim, \\
Edilenler & & prematürelik) \\
& & $\bullet$ Mahremiyet eğitimi \\
& Çocuk Psikolojisi Konuları & $\bullet$ Evlat edinme/koruyucu ailelik \\
& & bağlamına özel konular \\
\hline
\end{tabular}

Katılımcıların bebeklik dönemiyle ilgili merak ettikleri konulara ilişkin olarak fizyolojik gereksinimler alt kategorisinde katılımcılardan koruyucu aile olan İlke, çocukların gelişimsel Özelliklerinden fiziksel gelişimleri ve beslenme konusu hakkında merak ettiklerini "Aslanda bütün konular merak ediyoru₹. Fizilesel gelisimini ben mesela merak ediyorum. Hangi ayda hangi boyda, hangi kiloda olur? Yemekle ilgili ne yedirmeliyim sağhlkh bir beslenme plan olusturabilmek için...” sözleriyle belirtmiştir. Bunlara ek olarak gelişimsel özellikler koduyla ilgili, Fulya ise bebeğinin kendisini ne zaman ve nasıl tanıyacağını bilmek istediğini "Beni ne zaman tanır ya da kokumu ne kadar çabuk hisseder ya da daha mı

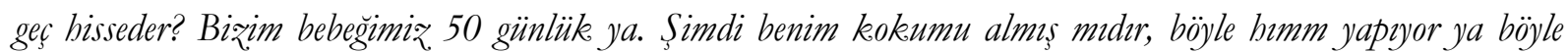


sinirleniyor, böyle aryyor beni. Acaba o kokumu bissettiği için mi normalde bütün bebekler mi böyle? Bunu ben çok merak ediyorum." ifadesiyle anlatmıştır. Koruyucu aile olan bir diğer katıllımcı Erkan ise "Mesela en basitten ne kadar uyuyabilir bir çocuk...” açıklamasıyla uyku konusunda bilgilendirilmeye ihtiyaçlarının olduğunu söylemiştir.

Çocuk psikolojisi konularıyla ilgili ise evlat edinme/koruyucu ailelik bağlamına ilişkin olarak İlke rumuzlu katılımcı bu durumun nasıl söyleneceğini merak ettiğini "Öz̨ellikle evlat edinme ya da koruyucu aile olunduğunu ne zamandan itibaren ne șekilde alghlyyorlar, ne șekilde konusmalynz?? Seçtiğimiz. kelimeler ne olmall, etrafimı̨qdaki insanlar bunlarla ilgili çocuklara ne söyleyebilirler?” sözleriyle belirtmiştir. Aynı katılımcı sosyal çevre etkileriyle ilgili “...biz. onlara hangi dönemde nasıl davranmalıyı?? E bir de bunun

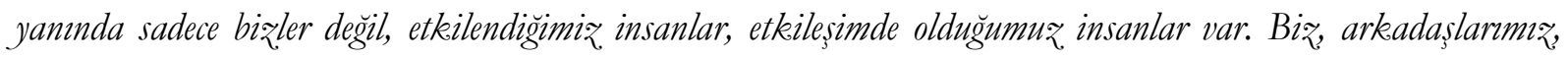
ailelerimiz var, onlarn da davramıs biçimleri var. Mesela ben onlarn etkilerini de her zaman çok merak ederim." ifadesinde bulunmuştur.

\section{Yeterlilikler, Yetersizlikler ve Güçlükler}

Çocukları bebeklik döneminde olan evlat edinen ve koruyucu ailelerin kendilerini ebeveynlikle ilgili hangi konularda yeterli, hangi konularda yetersiz hissettikleri ve sosyal çevreyle ilgili yaşadıkları güçlüklerin neler olduğu merak edilmiş, ailelerden bu konular hakkında fikirlerini paylaşmaları istenmiştir. Gelen yantlar; "Yeterli hissedilen konular, Yetersiz hissedilen konular ve Sosyal çevreyle ilgili yaşanan güçlükler" olmak üzere üç alt kategoride toplanmıştır. Bu alt kategoriler ve kodlara Tablo 5 'te yer verilmiştir.

Tablo 5. Yeterlilikler, yetersizlikler ve güçlükler

\begin{tabular}{|c|c|c|}
\hline Kategori & $\begin{array}{c}\text { Alt } \\
\text { Kategoriler }\end{array}$ & Kodlar \\
\hline \multirow{3}{*}{$\begin{array}{l}\text { Yeterlilikler, } \\
\text { Yetersizlikler } \\
\text { ve Güçcükler }\end{array}$} & $\begin{array}{l}\text { Yeterli } \\
\text { Hissedilen } \\
\text { Konular } \\
\end{array}$ & - Sevgi \\
\hline & $\begin{array}{l}\text { Yetersiz } \\
\text { Hissedilen } \\
\text { Konular }\end{array}$ & $\begin{array}{ll}\text { - İnatlaşma/bebeği ikna etme } \\
\text { - } \\
\text { - Uğlama } \\
\text { - } \quad \text { Doğru düzeni } \\
\text { - İstenmitim yöntemine karar verme davranı̧̧lar konusunda yapılabilecekler }\end{array}$ \\
\hline & $\begin{array}{l}\text { Sosyal } \\
\text { Çevreyle ilgili } \\
\text { Yaşanan } \\
\text { Güçlükler }\end{array}$ & $\begin{array}{l}\text { - Sosyal çevrede kabul sorunları } \\
\text { - Çevre desteğini alamama }\end{array}$ \\
\hline
\end{tabular}

Evlat edinen ve koruyucu aileler yapılan görüşmede, kendilerini yeterli hissettikleri konunun sadece "sevgi" olduğunu dile getirmişler hatta katılımcılardan koruyucu aile olan İlke "Ben biçbir konuda yeterli bissetmiyorum. Mümkün değil yani ben öyle hissetmiyorum.” diyerek kendisini hiçbir konuda yeterli 
görmediğini belirtmiştir. Yetersiz hissedilen konularda da ebeveynler, çocuklarının aslında gelişimsel özelliklerini de yansitan "inatlaşma/bebeği ikna etme, ağlama ve uyku düzeni” meselelerini anlatmışlar, "doğru eğitim yöntemine karar verme ve istenmeyen davranıslar karşında yapılabileceklerle" ilgili de yetersiz hissettiklerini dile getirmişlerdir. Sosyal çevreyle ilgili yaşanan güçlükler alt kategorisinde evlat edinen ve koruyucu aileler yaşadıkları en büyük güçlüklerin ise "sosyal çevrede kabul sorunlar ve çevre desteği alamama” konularında olduğunu ifade etmişlerdir.

Yeterli ve yetersiz hissedilen konularda ilk olarak kendilerini yeterli hissettikleri konu olan "sevgi" kodu incelendiğinde koruyucu aile olan Nida'nın "Ben annesi kadar sevdiüimi düşünüyorum. Doğuran annesi kadar. Hiç o konuda kendimi eksik hissetmiyorum.” şeklinde çocuğuna duyduğu sevgisini anlatmas1 dikkat çekmiştir. Kendilerini yetersiz hissettikleri konularda ise Fulya sevgi konusunda yeterli olduklarını düşünseler bile çocuklarının ağladıkları zamanlarda onları sakinleştirme gibi zorlu durumlarda yetersiz olduğunu "Bir de sevgi olduğunu söylüyorsunuz ama ben şimdi kendime güvenen, tuttuğumu koparan birisiyim, ama bebekle beraber eșim bana baz̧en diyor ki yapma bunu ağgyor elim ayağım titriyor, alp böyle sarllyorum, sarlyyorum, korkuyorum bir şey olacak diye aklm ģıkıyor. Böyle bir şey olur mu bir kere mesela böyle ağlarken olmuştur siz̨in de böyle simsiyab oldu, annem de yaşamıș onu. Annem diyor ki kalbim duracak sandim yavrum bir șey oldu sandim diyor yani o kadar bilmediğim bir șey." sözleriyle belirtmiştir. Kendilerini yetersiz hissettikleri bir diğer konu olan inatlaşma/bebeği ikna etme durumunda bebeklerini ikna etmeyi koruyucu aile olan Dilber "Ben şöyle, ikna edemediğimi düşünüyorum. Neden edemiyorum onu da bilmiyorum. Yani her şeyi veriyorum çok da seviyorum. 2 yass 3 ay, çok da tatlı bir kıฉ”" ifadesiyle anlatmıştır. Yetersiz hissedilen konularda doğru öğretim yöntemine karar verememe koduna örnek olarak koruyucu aile olan İlke düşüncelerini "Bir şey öğretmeye çalşsyorsunu₹:

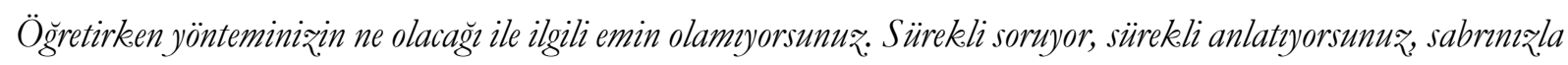
da alakah tabi, belli bir noktadan sonra. Anlatım biçiminiæi, kullandĭğmz kelimeleri, ne tür kelimeler kullanacağını̨, çok net olamıyorsunuz, emin olamıyorsunuæ:” şeklinde anlatmıştır.

Sosyal çevreyle ilgili yaşanan güçlükler alt kategorisinde sosyal çevrede kabul sorunları koduna örnek olarak koruyucu aile olan Nida düşüncelerini; "Kabul ettirmede ben uğraștım. Ben bir tek kabul ettirmede, çok ciddi direnç gösterdim. Büyük ablasindan (biyolojik çocuk) ayıram, kabul etmeyeni... sadece bayramdan bayrama görïşüyorum onlarla." sözleriyle belirtmiştir. Çevre desteğini alamama kodunda ise Dilber' in "2 ynl bekledik biæ. Beklerken kimse destek olmadı bana. Yani tamam eşim de destek oluyordu ama konuşmak istiyordum ha bire. Bir çorap alyyordum onu paylașmak istiyordum. Yani ne bileyim, kaynnvalidemden olsun, yani akrabalardan, yani destekliyorlardı hepsi ama ben açtıkģa millet sıkıllyor gibi hareket yapıyorlard.." ifadesi dikkat çekmektedir. 


\section{Bebeklik Dönemiyle İlgili Bilgilerin Öğrenildiği Kanallar}

Evlat edinen ve koruyucu ailelerin bebeklik dönemiyle ilgili bilgilerini hangi kanalları kullanarak öğrendikleri merak edilmiş ve katılımcılara bu kanallar sorulmuştur. Ailelerden gelen yanıtlar doğrultusunda, bebeklik dönemiyle ilgili bilgilerin öğrenildiği kanallar kategorisi; "profesyoneller, deneyimler ve diğer" olmak üzere üç alt kategoriye ayrılmış ve Tablo 6'da sunulmuştur.

Tablo 6. Bebeklik dönemiyle ilgili bilgilerin öğrenildiği kanallar

\begin{tabular}{|c|c|c|}
\hline Kategori & Alt Kategoriler & Kodlar \\
\hline \multirow{3}{*}{$\begin{array}{c}\text { Bebeklik } \\
\text { Dönemiyle } \\
\text { İlgili } \\
\text { Bilgilerin } \\
\text { Öğgrenildiğ } \\
\text { i Kanallar }\end{array}$} & Profesyoneller & $\begin{array}{ll}\text { - } & \text { Doktorlar } \\
\text { - } & \text { Pedagoglar } \\
\text { - Kurumdaki uzmanlar }\end{array}$ \\
\hline & Deneyimler & $\begin{array}{l}\text { - Kişisel deneyimler } \\
\text { - Çocuğu olan ailelerin deneyimleri } \\
\text { - Aile Büyüklerinin deneyimleri }\end{array}$ \\
\hline & Diğer & - - İnternet \\
\hline
\end{tabular}

Katılımcıların bebeklik dönemiyle ilgili bilgileri öğrendikleri kanallara verdikleri yanıtlarının çoğunda birden fazla alt kategoriye ve koda ait aç1klamalar bulunmaktadır. Örneğin; İlke "Evet araștrryoru y yani çevremizdeki deneyimlilerden, büyükklerimizden, doktorlardan, pedagoglardan, buradaki u₹man arkadaslarmı dan zaman zaman kimden ne bilgi alabilirsek aslinda neyi merak ediyorsak soruyoru₹:" ifadesiyle hem profesyoneller alt kategorisinde yer alan doktorlar, pedagoglar ve kurum uzmanları kodlarını hem de deneyimler alt kategorisinde yer alan aile büyüklerinin deneyimleri kodunu yansitan bir açıklamada bulunmuştur.

Nida ile Erkan arasında ise şu şekilde bir diyalog gerçekleşmiştir:

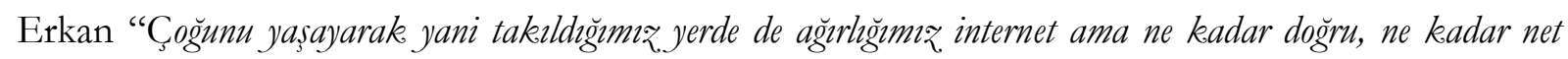
bilgiler diye tereddüt de ediyoru₹:" ifadesinde bulunmuş hemen arkasından Nida "Hem internet hem de cocuklar olan ailelere soruyoruz:" diye eklemiş ve Erkan: "Yani \%80, \%90 çocuklar olan ailelerden, zaten başkea bilgi alacağımı k kişi de yok." sözleriyle diyaloğa devam etmiştir. Nida ve Erkan'ın ifadeleri deneyimler alt kategorisinde kişisel deneyimler ve çocuğu olan ailelerin deneyimleriyle diğer alt kategorisinde yer alan internet koduna örnek yanıtlardır.

Deneyimler alt kategorisindeki çocuğu olan ailelerin deneyimleri ile ilgili olarak Fulya ise duygularını "Bir arkadaşa soruyorsun diyor ki; ben şunu içirdim, şunu yaptım, geçti. Aman diyorum şimdi denesem mi denemesem mi benim bebeğim çok kü̧̈ük şimdi hasta masta olursa. O kadar çok endişe ediyorsun ki bu arada yapsam mi yapmasam m?? Sonradan diyoruz, ki bașka çare yok, en azından bir kerecik ayaklarna yağ sürdüm... Diyor ki dlşaridan bir şey almasin, kimyasal bir şey içmesin ama sağllk için yarar olan hani ovmayla falan 
gesebilecek seyleri... Ama en son dün kimyon verdik, onda karar kaldık. Bir damla verdim biraz. rahatladı. Deneyerek ögreniyorsunuг:” şeklinde açıklamıştır.

\section{Eğitimle İlgili Öneriler}

Evlat edinen ve koruyucu ailelerin bebek ve küçük çocuklanyla ilgili eğitim ihtiyaçlanını belirlemeyi amaçlayan bu çalş̧mada ailelere, eğitimle ilgili önerilerinin neler olduğu sorulmuştur. Ailelerin ifadeleri incelendiğinde verilen öneriler "Eğitim içeriği/Mikro düzey ile Toplumsal Farkındalığın Artırılması/Makro düzey" olmak üzere iki alt kategoriye ayrılmıştır ve bu kategorilere Tablo 7'de yer verilmiştir.

Tablo 7. Eğitimle ilgili öneriler

\begin{tabular}{|c|c|c|}
\hline Kategori & Alt Kategoriler & Kodlar \\
\hline \multirow[t]{2}{*}{$\begin{array}{l}\text { Eğitimle } \\
\text { İlgili } \\
\text { Öneriler }\end{array}$} & Eğitim İçeriği/Mikro Düzey & $\begin{array}{ll}\text { - Evlat edinilen/koruyucu aile bakımında olan } \\
\text { çocuğa bu durumun açıklanması } \\
\text { - Çocuğun sosyal çevre tarafından kabulü } \\
\text { - Güvenli bağlanmanın gerçekleşip } \\
\text { - } \quad \text { Çerçekleşmediği } \\
\text { uzman desteği } \\
\text { uzman }\end{array}$ \\
\hline & $\begin{array}{l}\text { Toplumsal Farkındalığın } \\
\text { Artırılması/Makro Düzey }\end{array}$ & $\begin{array}{l}\text { - Hizmet içi eğitimler } \\
\text { - } \quad \text { İlgili bakanlıklarla iş birliği }\end{array}$ \\
\hline
\end{tabular}

Eğitim konusunda önerilerini dile getiren katılımcılardan Dilber, Eğitim İçeriği/Mikro Düzey alt kategorisinde evlat edinilen/koruyucu aile bakımında olan çocuğa bu durumun açıklanmasılyla ilgili görüşünü "Koruyucu aile bakımında olduğunu hangi yas aralğ̆nda söylememiz, gerekiyor? Yani bangi dönemde nasıl anlatmamı gerekiyor?” şeklinde ifade etmiştir.

İlke "Koruyucu aile, evlat edinen ailelerin iki temel konusu, bunu çocukla nasul paylaşacağrz? Toplumla nasıl paylaşacağz?? Bu eğitimin içerisinde bu ikisi mutlaka olmal. Bir diğeri de güvenli bağlanmaktan bahsediyoruz: Güvenli bağlanmanın olması için biz, ne tür davranıslar sergilemeliyiz?? Şimdi güvenli bağlanmış mı bu çocuk. bana, ben nereden biliyorum? Dolayısiyla bu modülün içerisinde bu da olmalı.” sözleriyle evlat edinilen/koruyucu aile bakımında olan çocuğa bu durumun açıklanması, çocuğun sosyal çevre tarafından kabulü ve güvenli bağlanmanın gerçekleşip gerçekleşmediği kodlarını içeren bir açıklama yapmıştır. Ayrıca aynı katılımonın "Şu ana kadarki deneyimlerim; ailelerin eğitilmesi ve ailelerin gerektiği yerde hangi uzmandan bangi desteği alacağım bilmesi gerekir" ifadesi çocukların gelişimsel dönemleriyle ilgili uzman desteği alınması koduna örnek olarak verilebilir.

Toplumsal Farkındalığın Artırılması/Makro Düzey alt kategorisinde İlke "Milli Ë̆itim Bakanluğ’’la görüsmeler yapıyoruz: Müfredata, Milli Eğitim müfredatına ilkokuldan itibaren evlat edinmeyi ve koruyucu aileliği koymamı lazım ve bütün rehberlik ögretmenlerinin bu konuda eğitim alması lą̧m. Ama temel sorun șu, șu anda baž bakanllklar birçok şeyden bihaber. Maliye Bakanlĭg bize ödenenler ve çocuğun devlete maliyetinden bibaber,

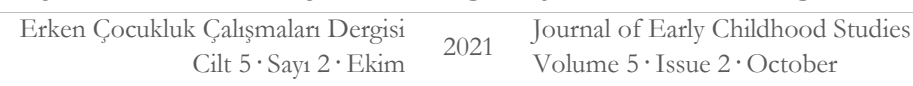


gidip anlatılması gerekiyor.” açıklamasıyla hem ilgili bakanlıklarla iş birliği yapılmasına hem de öğretmenlerin hizmetiçi eğitim almasına vurgu yapmıştır.

\section{SONUÇ ve TARTIŞMA}

Evlat edinen ve koruyucu ailelerin eğitim ihtiyaçlarını belirlemek amacıyla yapılan bu çalışmada elde edilen bulgular bebekliğe bakış, bebekle ebeveyn arasındaki ilişkiye bakış, bebeklik dönemiyle ilgili merak edilenler, yeterlilikler, yetersizlikler ve güçlükler, bebeklik dönemiyle ilgili bilgilerin öğrenildiği kanallar ve eğitimle ilgili öneriler kategorilerinde ele alınmıştır. Bu kategorilerde incelenen bulgular alanyazın taramasıyla ulaşılan bilgiler ve araştırma sonuçları ışığında tartışılmıştır. Bebeklik, hayatın ilk iki yılını kapsayan gelişimsel açıdan en kritik zamanlar olarak tanımlanmaktadır (Santrock, 2015; Berk, 2013). Gelişimsel öneminin yanında sosyolojik açıdan da bu döneme yönelik algıların ortaya çıkarılması çocuklarla ilgili hizmetleri ve politikaları etkileyeceğinden, son derece gerekli görülmektedir. Alan yazında bütün olarak çocukluk kavramının incelendiği ve yetişkinlerin çocukluğa bakışlarının nasıl olduğuyla ilgili birçok çalışma bulunmaktadır (Avcı ve Pekince, 2018; Kunt-Bulut ve Avc1, 2016; Pekince ve Avc1, 2018; Sorin, 2005) Ancak bebeklik, ilk çocukluk, orta çocukluk ve ergenlik dönemlerinden (Santrock, 2015) oluşan "çocukluk" çağına ilişkin bakış açılarının bu dönemler özelinde ayrı ayrı incelenmesi ve gelişimsel evrelere ayrıldığında farklılaşıp farklılaşmadığı merak konusu olmaktadır. Buna ek olarak 0-24 ay arasında çocuğu olan evlat edinen ve koruyucu ailelerin bebeklik dönemine bakış açılarının ortaya konulması onlara verilecek eğitim desteklerinin temelini oluşturacă̆ 1 için önemli görülmektedir.

Bebeklik dönemiyle ilgili evlat edinen ve koruyucu ailelerin görüşleri bebeklik anlayışı kategorisinin altında yüceltilmiş çocuk, yetersiz çocuk ve ebeveynin içsel süreçleriyle ilgili yanıtlar olmak üzere üç alt kategoride incelenmiştir. Yüceltilmiş çocuk ve yetersiz çocuk alt kategorilerinde ailelerin bir kısmının bebekliği; "aşk, sonsuz, sevgi, tath, minnoss, sevimli ve prenses” gibi abartılmıs duygularla, bir bölümünün de "korunmaya mubtaş, sürekli bakım gerektiren, eğitilmesi gereken kücülk insan, yaramaz, saf, masum ve melek" gibi gelişmemiş ve desteğe gereksinim duyan varlıklar şeklinde tanımladığı görülmektedir. Katılımcıların özellikleri düşünüldügünnde, evlat edinme ve koruyucu aile olma süreçlerini de göz önünde bulundurmak gerekmektedir. Bu durumu özellikle ailelerin yüceltilmiş çocuk alt kategorisinde verdikleri yanıtlar ışığında değerlendirince; ilk olarak akla, ailelerin çocuklarına kavuşma sürelerinin uzunluğu ve bu sürede yaşadıkları duyguların yoğunluğu gelmektedir. Hatta kavuşma süreci öncesinde evlat edinme ya da koruyucu aile olmaya karar verme aşaması da bu yoğun duygulara temel hazırlamaktadır (Boyd-Webb, 2017; Tezel, Demirel ve ŞahinKaya, 2018). Bütün bunlar düşünüldüğ̈nde ailelerin çocuklarıyla buluşma süreçlerinin çok uzun 
olduğu açıktır. Yüceltilmiş çocuk alt kategorisinde yer alan ve bir bebeğe olduğundan fazla anlam yükleyen bu romantik yanıtların da ailelerin farklı beklentiler içerisinde geçirdikleri hazırlık süreçlerinin bir yansıması olduğu düşünülmektedir. Aynı şekilde yetersiz çocuk anlayışında belirtilen bebekliğin gelişmemiş ve yetersizliğine vurgu yapılan görüşlerinin de ailelerin bu süreçlerinden kaynaklanabileceği sanılmaktadır.

Farklı bir açıdan bakılacak olursa katılımcıların "assk, sonsuz, sevgi...” ve "korunmaya mubtaç, sürekli bakım gerektiren...” gibi bebek denildiğinde akıllarına gelen ifadelerinin yüksek oranda olumlu özellikleri içeren yüceltilmiş çocuk anlayışıyla, bakım ve korunma ihtiyacını kapsayan yetersiz çocuk anlayışı olarak iki farklı durumu yansıtmalarıdır. Bu farklılıkların ikicilik diğer adıyla düalistik bakış açısıyla tanımlanabileceği akla gelmektedir. Çocukluğa ilişkin inanç ve yaklaşımların düalistik bakış açısıyla şekillendiği birçok çocukluk çalışmacısı tarafindan vurgulanmaktadır (James, A., 2010; James, A.L., 2010; Prout, 2011; Ryan, 2012). Düalistik bakış açısı, karşıt fikirlerden birini benimseyip diğerinin yok sayılmasına neden olabilir. Bu yüzden Prout (2011) düalizmin çocukluğa bakıştaki sınırlılığını vurgulayarak çocukluğun her iki düşüncenin de karmasıyla oluştuğunu belirtmektedir. Bu bilgiler 1şığında ilk sonuç olarak çalışmaya katılan evlat edinen ve koruyucu ailelerin yüceltilmiş çocuk anlayışıyla yetersiz çocuk anlayışı gibi farklı duyguları içeren bir bebeklik anlayışına sahip olduğu söylenebilir. Ancak katılımcıların yanıtlarına daha derin bakabilmek için alan yazında yer alan çocukluk tipolojilerini kısaca tanımlamak uygun olacaktır. Çocukluğa bakışın kategorilere ayrılmasını sağlayan özellikle gündelik uygulamalara ilişkin rehber olabilecek farklı çocukluk tipolojileri görülmektedir (Avc1, N., 2019; Haring, Sorin ve Caltabiano, 2019; Sorin, 2005). Bu tipolojiler arasında çocukluk çalışmacısı Sorin’in (2005) bütüncül bir bakış açısıyla oluşturduğu “on imaj” yaklaşımı bulunmaktadır. Bu yaklaşıma göre çocukluk; masum çocuk, çığ gibi büyüyen çocuk, kurban çocuk, kötü çocuk, kurtarıcı çocuk, kontrolden çıkmış çocuk, eğitime devam eden yetişkin, mülk olarak görülen çocuk, minyatür yetişkin ve katılımcı çocuk olmam üzere on farklı bakış açısıyla ele alınmıştır (Haring, Sorin ve Caltabiano, 2019; Sorin, 2005). Bu araştırmada da katılımcıların yanıtları incelendiğinde "korunmaya mubtaç, sürekli bakım gerektiren, saf, masum ve melek" gibi Sorin'in (2005) masum çocuk imajını yansıtan ifadelerinin olduğu görülmektedir. Bebeklik döneminin insan hayatında başkalarının desteğine gereksinim duyulan en hassas yıllar olması, bu dönemin korunmaya muhtaç, bakım gerektiren gibi ifadelerle tanımlamasına yol açabilmektedir. Ancak her bireyin gelişimi için doğuştan gelen bir eğilimi olduğu ve bu eğilimin sosyal çevrenin desteğiyle ortaya çıtı̆̆ı öz belirleme kuramının (Deci ve Ryan, 2000) önemle vurguladığı bir noktadır. Burada belirtilen desteğin çocukların özerklik ve yetkinlik gibi psikolojik gereksinimleri (Deci ve Ryan, 2000) göz önünde tutularak alg1lanması çok önemlidir. Kısacası; çocukların, gereksinimlerine uygun olanaklar içinde mutlu ve katılımcı olarak büyüme ve gelişmesi, yetişkinlerin 
çocuğa bakış açıları ve çocuk katılımı anlayışlarının "katılımcı çocuk" perspektifi doğrultusunda geliştirmesiyle mümkün olabileceği düşünülmektedir (Sorin, 2005; Birleşmiş Milletler Çocuk Haklar1 Komitesi, 2009).

Çocukluk anlayışıyla ilgili yapılan başka çalışmalara bakıldığında; araştırmalardan Avcı vd.'nin (2014) öğretmen adaylarıyla, Kunt-Bulut'un (2015) okul öncesi öğretmenleriyle, Balasar'ın (2019) yetişkinlerle yaptıkları çalışmaların bulgularında katılımcıların tüm çocukluk dönemini tanımlarken de muhtaç, masum, saf gibi sıfatları kullandıkları görülmektedir. Bu durumun; bebeklik dönemini saf, masum olarak tanımlayan ailelerin sadece gelişimsel açıdan değil sosyolojik açıdan da çocuklarını kendi hayatlarının etkin öznesi olarak değil de yetişkinlerin desteğine gereksinimi olan yetersiz varlıklar olarak görebilecekleri düşüncesini akıllara getirmektedir. Ayrıca, katılımcıların bebeklerini yetişkin bakımına gereksinim duyan yetersiz çocuk imajıyla yansıtmalarının bir başka nedeni, herhangi bir nedenle biyolojik ailesinden ayrılmak durumda kalan çocukların bir aile bakımına ihtiyaçlarının olduğunu düşünmelerinden de kaynaklanabilir. Avc1, Ü.E.'nin (2019) çalışmasında bir koruyucu ailenin bu durumu destekler nitelikte ". . o çocuk bana "anne” dedi ... Tamam biyolojik olarak annesi değilim ama bu çocuk bana mubtaç yani. Beş yaşsndayd ve bana "anne" diyordu ... Bu çocuk beni seviyor, ibtiyaçlarm bana söylïyor ... "şeklinde bir açıklama yaptığı da görülmektedir. Tezel, Demirel ve Şahin-Kaya'nın (2018) çalışmasında da koruyucu ailelik 'Bir çocuğun hayatın kurtarmaktır, ona sahip çıkmak, sevmek ve topluma kazandırmaktır” ifadesiyle tanımlanmıştır.

Evlat edinen ve koruyucu aileler ebeveynin içsel süreçleriyle ilgili yanıtlar alt kategorisinde de; "sorumluluk, yorgunluk, evlat, koruma isteği, sabır, ilgilenmek, buzur, mutluluk, heyecan, cossku, öncelik, bağhllk, değer, can, güven ve nefes" gibi çocuklarını düşündükleri zaman çocuklarının iç dünyalarında uyandırdığ1 duyguları tanımlamışlardır. Piel vd. (2017) biyolojik ailelerin kendi çocuklarının güvenliklerini ve refahlarını sağlayamadığı bir dünyada evlat edinen ve koruyucu ailelerin çocuklarla ilgilenme konusunda önemli bir sorumluluk duyduklarını vurgulamaktadır. Ayrıca evlat edinen ve koruyucu ailelerle yapılan çalışmalarda da ailelerin özellikle sorumluluk duygusunu vurguladıkları görülmektedir. Örneğin; Mallette, Almond, ve Leonard 'ın (2020) koruyucu ailelerin resmi ve resmi olmayan destek ihtiyaçlarıyla ilgili yaptıkları araştırmalarında koruyucu aileler çocukları, aile ilişkileri üzerine etkisi olan büyük bir sorumluluk olarak tanımlamışlardır. Tezel, Demirel ve Şahin-Kaya'nın (2018) çalışmasında da bir katılımcı, koruyucu aile olmanın hayatta birçok şeyi öğrettiğini en başta da sorumluluk almayı öğrendiklerini dile getirmiştir. Diğer taraftan MacGregor, Rodger, Cummings ve Leschied'in (2006) koruyucu ailelerin ihtiyaçlarını belirlemeye yönelik yaptıklanı nitel bir araştırmada, koruyucu ailelerin çocuklara duydukları sevgi ve bağlllık nedeniyle çocukların hayatlarında bir fark yaratma isteğinin içsel değerleri tarafından motive edildiği ortaya konulmuştur. Bu çalışmada ailelerin çocuklarıyla aralarındaki ilişkiyi "sevgi, sorumluluk, bağhllık" gibi kendi içsel 
süreçlerini anlatan yanıtları aslında tıpkı MacGregor vd. (2006) çalışmasında olduğu gibi onları ebeveyn olmaya motive eden duygular olarak yorumlanabilir. Daniel'in (2011) koruyucu ailelerin bakış açılarıyla ilgili yaptığı çalışmada da ailelerin sevgiyi en önemli içsel motivasyon olarak tanımladığ1 görülmektedir. Bu noktada merak edilen evlat edinen ve koruyucu ailelerin ebeveyn olmalarını motive eden duygularının sadece evlat edinen ve koruyucu aile durumlarından kaynaklı olup olmadığıdır. Annelikle ilgili yapılan bir çalışmada; evlat edinen anne, koruyucu anne ve biyolojik annelerden oluşan katılımcıların tamamı, anne olmanın biyolojik olarak tanımlanamayacağını ve bunun çocuk ile geliştirilen ilişki üzerinden gerçekleştiğini ifade etmişlerdir (Avcı, Ü.E. 2019). Bu çalışmadaki ailelerin içsel süreçleriyle ilgili tanımladıkları ve onları ebeveyn olmaya motive eden duyguların diğer çalışmalardaki hem evlat edinen ve koruyucu ailelerin duygularıyla hem de biyolojik annelerin duygularıyla tutarlı olduğu söylenebilir.

Evlat edinen ve koruyucu aileler, bebekle ebeveyn arasındaki ilişkiye bakış kategorisinde çocuklarıyla aralarındaki ilişkiyi çocuk bağlamında "aşk, sevgi, oyun ve bağ” gibi ifadelerle açılklarken, kendi bağlamlarında "şaşkmlık, acemilik, yorgunluk, baş başa kalmca tereddüt/yetersizllik, özlem, mutluluk, beyecan, bağhllk, güven ve bu₹ur" şeklinde tanımlamışlardır. İlk olarak çocuk bağlamında verilen yanıtlara bakılacak olursa dikkat çekici kısım; katılımcıların aradaki ilişki sorulduğunda bebeklik anlayışı kategorisinde verdikleri yanıtlardan farklı olarak çocuğun doğasını yansıtan "oyun” kelimesini söylemesidir. İlişki gibi karşılıklı durumlarda bebeklik anlayışı yetersiz ve yüceltilmiş çocuk olan kişilerin bile çocuğun doğasını yansıtıcı cevaplar vermesi ilgi çekici bulunmuştur. Çünkü bu yanıt öz belirleme kuramında belirtilen, kişinin gelişim için doğuştan gelen bir eğilimi olduğu ve bu eğilimin sosyal çevrenin desteğiyle ortaya çıktığı (Deci ve Ryan, 2000) tanımının ufak bir yansıması olarak görülebilir. Çocukların doğuştan gelen bu eğilimleri için özerklik gibi psikolojik ihtiyaçları vardır (Deci ve Ryan, 2000). Özerklik desteği, çocuğun bakış açısının ve ihtiyaçlarının ne ölçüde dikkate alındığından, yetişkin tutumlarından ve katılımın nasıl sağlandığından etkilenmektedir (Joussemet, Landry ve Koestner, 2008). Çocukların gelişim özellikleri düşünüldüğünde de oyun; çocuğa kendini anlatma, yeteneklerini anlama ve tüm gelişim alanlarını desteklemede önemli bir rol almakta, sosyal çevrenin desteği noktasında ebeveynin yararlanacağı iyi bir araç olmaktadır.

Evlat edinen ve koruyucu ailelerin çocuklarıyla ilişkileri hakkında vurguladıkları diğer duygularda ise özellikle annelikte-babalıkta salgılanan ve bağlanma için önemli olan oksitosin yani sevgi hormonunun etkileri görülmektedir. MacGregor vd.'nin (2006) koruyucu ailelerin ihtiyaçlarını belirlemeye yönelik yaptıkları çalısmada ortaya konulan ve ailelerin tüm yorumları boyunca tutarlı olan nokta çocuklara karşı güçlü bir sevgi ve bağlılık hissettikleri olmuştur. Ayrıca bu çalışmadaki "aşk" yanıtına benzer olarak MacGregor vd. (2006) çalışmasında da bir koruyucu aile çocukları ilk 
aşkı olarak tanımlamıştır. Ebeveynle bebek arasında gerçekleşen bağlanma temelli özel ilişkide sevginin rolü çok büyüktür. Ancak ebeveynler çocuklarının bağlanma kalitesi konusunda büyük bir sorumluluk taşırlar ve birçok stresle karşı karşıya oldukları için çocuklarına sürekli sevgi dolu karşıllık veremeyebilirler (Boyd-Web, 2017). Bu duruma yönelik katılımcıların kendi bağlamlarıyla ilgili verdikleri "şasskınlık, acemilik, yorgunluk, baş başa kalnca tereddüt/yetersiz̨lik, öẓlem, mutluluk, beyecan, bağhlık, güven ve buгur" yantlarını yorumlamak gerekmektedir.

İlk olarak katılımcıların ifade ettikleri duygular ışı̆̆ında ebeveynliği; mutluluk ve heyecan gibi yoğun duygular yaşarken insanın kendini yorgun, tedirgin ve acemi hissettiği bir süreç şeklinde tanımlamak mümkündür. Bir bebeğin gereksinimlerini karşılamak günde yirmi dört saat, haftada yedi gün süren bir eylemdir ve genellikle de çok endişe vericidir. Birçok insan için günümüzde bunlar tatsız gerçeklerdir (Bowlby, 2012b). Shklarski'nin (2019), evlat edinen / koruyucu ailelerin ebeveynlik becerileri ve ikilemleriyle ilgili yaptığı çalışmada katılımcılardan biri koruyucu aile olarak ebeveynlik sürecini şu şekilde tanımlamıştır "Çocuğunuฉu alirsmı, ve defteriniz randevular, ziyaretler, mabkeme taribleriyle dolar bu tam zamanh bir iştir." Ayrıca aynı çalışmada başka katılımcılar, koruyucu aile olmadan önce tam zamanlı çalıştıklarını sonra ya yarı zamanlı bir işe geçtiklerini ya da durumlarına uyacak daha esnek bir iş bulduklarını dile getirmişlerdir. Shklarski’nin (2019), çalışmasındaki ailelerin açıklamaları, bu çalışmadaki evlat edinen ve koruyucu ailelerin belirttiği acemilik ve yorgunluk kavramlarına benzer şekildedir. Ancak ebeveynlerin hissettiği bu güç süreçlerin yanında çocuklara karşı hissedilen sevgi ve çocuğun gülümsediği anda duyulan heyecan; yorgunluk gibi zorlu duyguları dengeleyerek ebeveynle çocuk arasındaki ilişkinin çift yönlü olduğunu kanıtlar niteliktedir (Bowlby, 2012b; Greenspan ve Lewis, 2006). Şu da unutulmamalıdır ki bebekler ebeveynlerinden sadece sevgi beklememekte, bu sevgiyi aktif bir ortaklıkla paylaşmak istemektedir (Greenspan ve Lewis, 2006). Avcı Ü.E.'nin (2019) çalışmasında evlat edinen bir anne de bu ortakllğı onaylar şekilde, anneliği “Emeğin karşıliğm sadece sevgi ile kat be kat aldĭğn bir ilişki” olarak tanımladığ1 görülmektedir. Ayrıca ebeveyn bebek arasındaki bu ortaklığı nörobiyolojik terimlerle açıklamak gerekirse anne/baba ve çocuğun göz göze gelmesi bile beyin yapısının gelişimi için önemlidir. Karşılıklı uyarılmanın olduğu bu etkileşimli sistemde beynin sağ tarafı olumlu etkinin yüksek olduğu sembiyotik bir duruma girerek, duygusal işlevlere dahil olan korteksin kenar bölgelerinin olgunlaşmasını sağlayacaktır (Masterson, 2013). Bu çalışmadaki evlat edinen ve koruyucu ailelerin çocuklarıyla aralarındaki ilişkiyi tanımlarken kullandıkları hem sevgi, mutluluk, heyecan gibi güzel duygular hem de sorumluluk, yorgunluk acemilik gibi zorlu duyguların aslında ebeveynliğin ve etkileşimin bir parçası olduğu söylenebilir.

Çalışmaya katılan ailelerin bebeklik dönemiyle ilgili merak ettikleri konular fizyolojik gereksinimlere yönelik konular ve çocuk psikolojisi konuları alt kategorilerinde toplanmıştır. Kendilerine verilecek 
bir eğitimin hangi konulan içermesini istedikleri sorulduğunda ise merak ettikleri konularda ifade ettiklerine atıf yaparak yine bu alanlarda bilgi edinmeye ihtiyaç duyduklarını söylemiş, sosyal çevre ile ilişkilerinde karşılaştıkları güçlükleri de önerilerine eklemişlerdir. Örneğin sosyal çevre ile ilişkilerinde karşılaştıkları güçlükleri hem merak edilenler kategorisinde hem de eğitimle ilgili öneriler kategorisinde değinmişlerdir. Bu nedenle bu kategoriler birlikte tartışılacaktır.

Merak edilenler kategorisinin fizyolojik gereksinimlere yönelik konular alt kategorisinde aileler; bebeklerin boy, kilo özellikleri, bakım vereni ebeveyn olarak tanıma gibi gelişimsel özellikleri ile beslenme, uyku, temel bakım gibi günlük rutinlerle ilgili çeşitli konularda bilgi ihtiyaçlarının olduğunu ifade etmişlerdir. Çalışmanın bulgularına paralel nitelikte farklı bir araştırmada annelerin bebek bakımı konusunda bilgi ve deneyim eksikliği olduğu belirlenmiştir (Pınar vd. 2009). Benzer şekilde Ertem vd.'nin (2007) araştırmasına göre üç yaş altında bebeği olan anneler, bebeklerinin fiziksel, sosyal-duygusal, bilişsel gelişim alanlarında hangi becerilerin yaklaşık olarak hangi dönemde kazanılması ya da gözlemlenmesi gerektiği ve yaşamın ilk aylarından itibaren gelişimi destekleyici yaşantıların nasıl sunulması gerektiği bilgisine sahip değildirler. Şahinöz ve Bütün-Ayhan'ın (2020) çalışmasına katılan anneler ise bebeklerinin gelişimleriyle ilgili yeterli bilgiye sahip olmadıklarını belirtmişlerdir. Bununla birlikte aynı anneler çocuk gelişimi uzmanlarından bilgi edinmenin, bebeklerinin gelişimlerine yönelik bilgi düzeylerini artırdığını ifade etmişlerdir. Ailelerin bebeklerle ilgili bu tür bilgi ihtiyaçlanının olması, ebeveynlere yönelik eğitim uygulamalarının gerekliliğini göstermektedir. Evlat edinme ve koruyucu aile bakım hizmetleri özelinde ise koruma kararı aşamasında ailenin, bebeğin fiziksel ve psikolojik sağlığı konusunda ilgili uzman tarafından bilgilendirilmesi gereklidir. Çünkü her bebeğin kendine özgü ihtiyaçları temelinde bir etkileşim alt yapısı oluşturmak, bu bağlamda gelişimsel ve psikolojik ihtiyaçlarına yanıt vermek, onun geçmiş yaşantılarından bağımsız düşünülemez. Evlat edinen ve koruyucu aile açısından değerlendirildiğinde ise bebeğiyle ilgili bilgi edinmek kişisel bir haktır ve bu hakkın kendilerine teslim edilmesi aşamasında çocuklarının sağlığıyla ilgili yaşanması olası güçlükler konusunda da bilgilendirilmelidirler (Özbesler, 2009).

Aileler çocukların gelişimsel dönemleriyle ilgili uzman desteğini nasıl alabileceklerine dair de bilgilendirilmeye ihtiyaç duyduklarını belirtmişlerdir. Öncelikli olarak ailenin çocuğun gelişimiyle ilgili bilgi sahibi olması gerekmektedir. Bu bilgi birikimleri, çocuğun yüksek yararının ne olduğunu belirlemede kullanılabilecek değerli bir kaynaktır (Geiger, Hayes ve Lietz, 2013). Çocukların gelişimsel değerlendirme süreçlerinin sağlıklı bir şekilde gerçekleştirilebilmesi için öykülerinin alınması aşamasında aileler uzmanlar için önemli bilgi kaynaklarıdır. Alanyazında, annelerin çocuklarının gelişimleriyle ilgili bir risk faktörünün olması durumunda güvenilir bir bilgi kaynağı 
olarak sağlık personeli gibi uzmanlanı bilgilendirebildiklerini göstermiştir (Emre-Bolatbaş ve YıldızBıçakçı, 2018; Karaaslan, 2016). Buna ek olarak, çocuklarının gelişimleri hakkında bilgi sahibi olan annelerin, çocuklarına gelişimsel destek sağlamada daha başarılı oldukları ve çocuklarının da daha iyi gelişimsel sonuçlara sahip oldukları görülmüştür (Dichtelmiller vd., 1992; Glascoe ve Dworkin 1995; Goodnow 1988; Miller, 1988). Ayrıca annelerin çocuk gelişimi hakkındaki artan bilgisinin; güçlü bir anne-çocuk etkileşimini, daha teşvik edici ev ortamlarını, çocuğun gelişiminin desteklenmesini ve çocuk istismarı risklerinin azalmasını sağlayacağı düşünülmektedir (Ertem vd. 2007). Bu nedenle ailelerin çocukların gelişimsel süreçleri ve hangi uzmandan nasıl destek alabileceği hakkında da bilgilendirilmeleri önemlidir.

Çalışmaya katılan aileler, bebeklik dönemiyle ilgili çocuk psikolojisi konuları alt kategorisinde evlat edinen ve koruyucu aile olma durumunun nasıl ve ne zaman söylenmesi gerektiğini, bu aşamada ve ilerleyen dönemlerde sosyal çevre etkilerinin neler olabileceğini merak ettiklerini ifade etmişlerdir. $\mathrm{Bu}$ durumun çocuğa nasıl açıklanacağının bilinmemesi, onunla daha geç paylaşılmasına sebep olabileceği gibi bazen de tamamen saklanılmasına yol açabilmektedir. Saklanılması durumunda çocuğun gerçeği başka bir kişiden öğrenmesi korkusu ailelerin kaygılanmasına sebep olmaktadır. Bununla birlikte Gökçe (2017) tarafindan yapılan araştırmada da bazı aileler, sosyal çevrenin evlat edinen bireye ve çocuğuna acıma duygusuyla yaklaştıklarını belirtmişlerdir. Bu yaklaşım, ailelerin evlat edinme durumunu gizlemelerine sebep olabilmektedir. Çocuğun ailesini benimsememesi ya da durumu öğrendiğinde verebileceği olumsuz tepkiler de yine ailelerin durumu paylaşmasına engel teşkil edebilmektedir. Altınoğlu-Dikmeer, vd. (2014) tarafından yapılan araştırmada; çocukların evlat edinilme durumunu öğrendikleri yaşın artmasıyla problem davranışlarla karşılaşma oranının yükseldiği görülmüştür. Bu durumun sebebi; bu bilginin çocuk tarafından kabullenilmesinin belirli bir süreç gerektirmesi, içselleştirmenin gecikmesiyle bu durumun oluşturduğu kaygının üstesinden gelmenin zorlaşması olarak görülmektedir. Tüm bu endişe ebeveyn-çocuk ilişkisine yansıyarak, problem davranışların tetikleyicisi olabilmektedir.

Çocuğun evlat edinme/koruyucu aile bakım hizmetinde olma durumunun saklanması çocuğun bulunduğu bütün ortamları kapsamaktadır. Örneğin; Nowak-Fabrykowski, Helinski ve Buchstein (2009) tarafından yapılan araştırmanın katılımcıların büyük bir kısmı; çocuklarının evlat edinilme durumunu okullarına bildirmemiştir ve bu durumun bilinmesini de istemediklerini belirtmişlerdir. Çünkü aileler çocuklarının “evlat edinilmiş çocuk” olarak etiketlenmesinden çekinmektedir. Çocukların toplum tarafindan etiketlenmesi problemi Gökçe'nin (2017) çalışmasına katılan aileler tarafindan da ifade edilmiş; çocuğun sosyal çevreye kabulünde dini ve ekonomik kaygılar nedeniyle sorun yaşadıklarını belirtmişlerdir. Toplumun ekonomik kaygılarının nedenini; evlat edinen kişilerin 
mal varlıklarının kişilerin kan yoluyla bağlı oldukları aile bireylerine kalması gerektiğinin düşünülmesiyle ilgili olduğunu, dini kaygılarının nedenini ise daha çok evlat edinmeyle ilgili dini hurafelere sahip olunmasıyla açıklamışlardır. Tezel, Demirel ve Şahin-Kaya (2018) tarafından yapılan araştırmada, evlat edinmek isteyen katılımcılar, ailelerinin karşı çıkması ve dini sebepler sonucunda evlat edinmekten vazgeçtiklerini, koruyucu aile olmaya karar verdiklerini belirtmişlerdir. Benzer şekilde Yıldırımalp ve Hız (2020) tarafından yapılan araştırmada da koruyucu aileler sosyal çevrelerinden, dini olarak bir sorun olup olmadığının sorgulanması gerektiği şeklinde tepkilerle karşılaştıklarını ifade etmişlerdir. Aileler sosyal çevrelerinin tepkisinin evlat edinmeye karşı olduğunu, koruyucu aile olmalarını ise desteklediklerini açıklamışlardır. Avcı, Ü.E (2019) tarafından yapılan çalışmada da evlat edinen ve koruyucu ailelerin başvuru sürecinde karşılaşabilecekleri tepkilerden dolayı, çevreleriyle bu durumu paylaşamadıkları belirlenmiştir. Yurtdışında yapılan araştırmalarda da benzer sorunların yaşandığı görünmektedir. Örneğin Miller-Ott (2017) tarafindan yapılan araştırmada aileler; insanların, çocuklarının koruyucu aile bakımında olduğunu öğrendiklerinde gösterdikleri tepkilerden rahatsız olduklarını belirtmişlerdir. Aynı zamanda çocuklar da koruyucu aile yanında olan ya da evlat edinilen çocuk olarak etiketlenmekten rahatsız olduklarını ifade etmişlerdir.

Araştırmamızda çocuğun; akraba, tanıdık kişiler gibi yakın sosyal çevreleri tarafindan kabul edilmediğini belirten ebeveynler, ailelerine bir çocuğun katılacağı sevincini ve ilgili hazırlıklar aşamasında duydukları heyecanı paylaşmada sorunlar yaşadıklarını anlatmışlardır. Başka bir çalışmada ise bir anne, çocuğun evlat edinilmesine olan yaklaşımların olumlu göründüğü ancak yine de kabul edilmemesinin üstü kapalı mesajlarla, atasözleriyle kendisine aktarıldığını belirtmiştir (Gökçe, 2017). Oysaki ailelerin, yakın arkadaşları ve kendi aileleriyle kurdukları destekleyici ve besleyici ilişki, koruyucu ailelerin durumla ilgili stres faktörlerini daha iyi idare etmesine olanak sağlamaktadır (Mallette, Almond ve Leonard, 2020). Bu stres faktörleri; sağlık sorunları yaşayan ya da travma geçmişi sebebiyle davranış problemleri olan çocukları evlat edinme, çocuğun biyolojik ailesiyle görüşmenin aidiyet ve gizlilik açısından bir risk olarak görülmesi şeklindedir (Julien-Chinn vd. 2017). Ailelerin bu ve benzeri stres faktörleriyle baş etme konusundaki yllmazlıklarına ise profesyonellerden ve/veya geniş aile, arkadaş gibi yakın çevreden alınan sosyal destek olumlu yönde etki etmektedir (Lietz ve Strength, 2011; Ross, Holliman ve Dixon, 2003).

Sosyal çevreye kabul boyutu sadece çocukla ilgili değil aynı zamanda evlat edinen ve koruyucu ailelerin sosyal çevrede kabulüyle de ilgilidir. Yapılan araştırmalarda evlat edinen ve koruyucu aileler, çocuklara sadece "bakım veren bireyler" olarak görülmekten rahatsız olduklarını ifade etmişlerdir (Avc1, Ü. E., 2019; Miller-Ott, 2017). Oysa katılımcılar, aile olabilmek için çocuğun biyolojik annesi 
ya da babası olmanın önemli olmadığını, önemli olanın çocukla kurulan bağ olduğunu ifade etmişlerdir. Çocuğun annesi, babası olarak değil de sadece bakım veren kişiler olarak görülme kayg1sı da ailelerin bu durumu saklama eğilimlerinin nedenlerinden biri olabilir (Miller-Ott, 2017).

Ailelerin tüm bu kaygılarını ilk paylaştıkları ve yardım istedikleri kişiler meslek elemanlarıdır. Meslek elemanlarının ailelerin bu konudaki kaygılarını anlamaları ve aileleri doğru yönlendirmeleri için bilgi ve deneyim sahibi olması gerekmektedir (Geiger vd., 2016; Geiger, Hayes ve Lietz, 2013; Hayes vd., 2015). Ancak yapılan araştırmalarda evlat edinen ve koruyucu ailelerin ilk danıştıkları merci meslek elemanları olsa da ailelerin meslek elemanlarını sosyal destek ve danışmanlık konusunda yetersiz buldukları görülmüştür (Avc1, Ü. E., 2019; Baysal, 2017; Geiger, Hayes ve Lietz, 2013; Karataş, 2007; Yıldırımalp ve Hız, 2020). Çalışmaya katılan ailelerin de ifade ettiği gibi, evlat edinen ve koruyucu aile biriminde çalışan meslek elemanlarının bu konuda deneyimli olması ve hizmet içi eğitimlere katılması gerekmektedir (Abukan, 2020).

Evlat edinen/koruyucu ailelerle çalışan meslek elemanlarının yanı sıra çocuklarla çalışan bütün profesyonellerin bu konuda bilgili olması gerekmektedir. Çocukla çalışan öğretmen, doktor, psikolog gibi uzmanlar farklı bakanlıklara bağlı bulunmaktadır. Bu nedenle bulundukları bakanlıkların iş birliği yapması da önemli bir diğer faktördür. Yıldırımalp ve Hız (2020) tarafından yapılan araştırmada da koruyucu aileler, çocuklarının okullarındaki rehberlik ve psikolojik danışmanlık öğretmenleriyle sosyal çalışmacıların iletişim halinde olması gerektiğini düşündüklerini belirtmişlerdir. Çocukla çalışan her profesyonelin bu konuda bilgi sahibi olabilmesi ancak ilgili bakanlıkların iş birliği yapmasıyla mümkün olacaktır (Piel vd., 2017).

Aile, Çalışma ve Sosyal Hizmetler Bakanlığının 2017 yılında yayınladığı Türkiye’de Çocuklara Yönelik Koruyucu ve Önleyici Politikaları Değerlendirme Çalıştayı Raporu’nda;

\footnotetext{
Personel ekseninde; insan kaynağının bilinçlendirilmesi, farkındalık düzeyinin yükseltilmesi amacıyla başta okul müdürleri, pansiyondan sorumlu müdür yardımcıları, rehber öğretmenler olmak üzere her yıl bölgesel olarak yapılan hizmet içi eğitimlerde bu konulara da yer verilmektedir (s. 24)
}

ifadeleri yer almaktadır. Raporda ayrıca "Kurumlarımızın koruyucu ve önleyici politikalarda karşılaştıkları en önemli sorun koordinasyon eksikliğidir. Çalışılması gereken temel unsur koordinasyonun sağlanmasıdır.” (s. 35) ibaresi çocukla çalışan uzmanların bilgilendirilmesinde daha fazla eğitime ihtiyaç olduğunu düşündürmektedir.

Aileler, eğitimle ilgili öneriler kategorisinde güvenli bağlanmanın gerçekleşip gerçekleşmediğiyle ilgili bilgi edinmek istediklerini de belirtmişlerdir. Bebeklerin bakım verenle ilişkisi ve bağlanma 
şekilleri; fiziksel, bilişsel, psikososyal gelişimlerini, yetişkinlik dönemindeki psikososyal sağlık ve iyi olma hallerini etkileyen önemli yapı taşlarıdır (Wright, 2001). Evlat edinme ve koruyucu aile bakım hizmetlerinde çocuğun güvenli bağlanabileceği bir yetişkin olsa bile, çocukların kuruma gelmeden önce yaşanmış travmalarının da olabileceği unutulmamalıdır (Perry ve Szalavitz, 2017). Ayrıca koruma-bakım hizmetinden yararlanan çocuklar için, kurum bakımında bulunma sürelerinin bakım verenle bağlanma ilişkisini olumsuz etkileyen bir diğer faktör olduğu da bilinmektedir. Bu nedenle travma geçmişi olan ya da kurum bakımında uzun kalan çocuklarda güvenli bağlanmanın gerçekleşmesinde bazı güçlükler yaşanabilir (Gopnik, 2015; Karataş, 2007; Perry ve Szalavitz, 2017). Kurum bakımından, evlat edinme/koruyucu aile hizmet modelinden yararlanma sürecine geçen çocuk ve bakım veren arasında kurulacak kuvvetli bir bağ sayesinde bu güçlüklerin aşılması beklenmektedir (Boyd- Webb, 2017; Perry ve Szalavitz, 2017). Bu nedenle ailelere güvenli bağlanma hakkında eğitim verilmesi kritik öneme sahiptir.

Çalışmaya katılan aileler kendilerini yeterli hissettikleri konular sorulduğunda "sevgi” yanıtını vermiştir. Özellikle anneler, bebeği dünyaya getirme konusuna vurgu yaparak biyolojik bir bağ olmasa da kuvvetli bir sevgi bağına sahip olduklarını açıklamışlardır. Avcı, Ü. E. 'nin (2019); biyolojik, evlat edinen ve koruyucu anne olan katılımcıların annelikle ilgili görüşlerini değerlendirdiği araştırmasında; anneler çocukla olan ilişkinin sevgiyle ödüllendirildiğine vurgu yapmış, bu çalışmaya katılan annelerin de ifadelerine benzer şekilde, annelik bağının mutlaka doğumla oluşmasına gerek olmadığını, bu bağın içgüdüsel bir his olduğunu belirtmişlerdir.

Ailelerin kendilerini yetersiz hissettikleri konular arasında bebeğin ağlamalarına nasıl yanıt verileceğinin ve uyku düzeninin nasıl oluşturulması gerektiğinin bilinmemesi, bebeğin gelissimi sırasında nasıl destekleneceğinin, bu anlamda hangi yöntemlerin etkili olacağının bilinmemesi ve istenmeyen davranışların nasıl önleneceğine karar verilememesi yer almaktadır. Benzer şekilde bir başka çalışmada koruyucu aileler, kendilerine temel ebeveynlik becerilerinin aktarılacağı bir eğitime gereksinim duyduklarını açıklamıştır. Bu eğitimin çocuklardaki davranışsal sorunlar, bağımlılık belirtilerinin neler olduğu, mahkeme süreçleri, yas ve ilişkilere odaklanan bir danışmanlık gibi yaşayabilecekleri özel durumları da içermesini önermişlerdir (Mallette, Almond ve Leonard, 2020). Başka bir çalışmada, anneler bebek bakımı ve gelişimi konularında danışmanlık hizmeti almaları sayesinde ebeveyn olarak yeterli olduklarını hissettiklerini ifade etmişlerdir (Şahinöz ve BütünAyhan, 2020).

Her ailenin danışmanlık alması mümkün olmasa da hem biyolojik aileler hem de evlat edinen ve koruyucu aileler, ailelerine yeni bir üyenin katılması fikrinden itibaren bebek bakımı ve gelişimi konusunda bilgi edinmeye çalışırlar. Bu bilgi edinme süreci tüm aile yapılarında benzer şekilde 
gelişmektedir. Hamilelik ya da evlat edinen/koruyucu aile olmaya karar vermeyle başlayan bilgi edinme sürecinde aileler birçok kaynağa başvururlar. Bu çalışmada da ailelerin bebeklik dönemiyle ilgili bilgileri öğrendikleri kaynakların; doktorlar, pedagoglar ve kurumdaki uzmanlar gibi profesyoneller, kişisel deneyimler, çocuğu olan ailelerin deneyimleri ve aile büyüklerinin deneyimleri gibi deneyim kaynakları ve internet kaynakları şeklinde olduğu görülmektedir.

Ailelerin farklı kaynaklardan bilgi topladığı bebeklik dönemi, gelişimin en hızlı olduğu dönemdir ve bu dönemdeki gelişimsel görevlerin bilinmesi, bebekten ne beklenmesi gerektiğinin de anlaşılmasını sağlamaktadır. Bu beklentilerin, bebeğin gelişimsel olarak yapabileceği düzeyde olması gerekmektedir. Smyke, Zeanah, Fox ve Nelson (2009) tarafindan yapılan araştırmada, evlat edinen ve koruyucu ebeveynlerin, çocuğun bulunduğu gelissimsel dönemde göstermesi beklenmeyen becerileri göstermesini beklediği ya da çocuğun göstermesi beklenen becerilerin neler olduğunu bilmedikleri görülmüştür. Benzer şekilde yapılan bir diğer araştırmada da annelerin çoğunluğu (\% 63.7) bebeklerinin gelişimleriyle ilgili yeterli bilgiye sahip olmadıklarını ve kendilerini yetersiz hissettiklerini ifade etmiştir (Şahinöz ve Bütün-Ayhan, 2020). Annelerin bebeğin bakımı ve gelişimiyle ilgili bilgi eksikliğinden doğan bu yetersizlik hissi, anne-bebek bağlanmasını olumsuz yönde etkileyecektir. Bu nedenle hem biyolojik aileler hem de evlat edinen ve koruyucu aileler için bebeklik dönemiyle ilgili verilecek eğitimlere ihtiyaç vardır.

Yapılan araştırmalara göre aileler birçok kanaldan bilgi toplamaya çalıssalar da bilgiyi bir uzmandan alan aile sayısı azdır ve genellikle bilgi kaynakları ebeveynin kendi annesi ya da bir aile üyesi olmaktadır (Hacıhasanoğlu-Aşılar ve Bekar, 2018; Kahraman, Kabalcığlu ve Ersin, 2016; Şahinöz ve Bütün-Ayhan, 2020). Aileler, Aile Sağllğı Merkezi’nde doktor, hemşire gibi uzmanlardan, kitap, dergi ve internet gibi kaynaklardan da bilgi edindiklerini ifade etseler de ailelerin çoğunlukla sosyal çevrelerinden bilgi almaya eğilimli oldukları görülmektedir (Batman, 2018; Hacıhasanoğlu-Aşılar ve Bekar, 2018; Kahraman, Kabalcı̆glu ve Ersin, 2016). Sosyal çevreden sağlanan bu bilgi desteği evlat edinen ve koruyucu aileler için çocuklarının travmatik deneyimlere sahip olma olasılıkları nedeniyle anne-bebek etkileşiminde daha önemli bir rol oynayabilmektedir. Dolayısıyla ebeveynler kurum sonrası, bebekler ve küçük çocuklarla deneyimlerinde daha fazla bilgi ve desteğe ihtiyaç duyabilirler. Böyle durumlarda bilgi edinilen kanallar yetersiz gelebilir. Bu durumla baş edebilmek için erken müdahale yaklaşımları benimsenmelidir. Bu amaçla hem meslek elemanlarına, hem de ailelere verilen destek oldukça önem kazanmaktadır (Smyke, vd., 2009). Gerek evlat edinme gerekse koruyucu aile olma aşamasında ailelerin yaşadıkları süreçler benzerlik göstermekte ve aileler kendilerini ifade etme, benzer sorunları-ihtiyaçları dile getiren kişilerle iletişim kurma, dinlenilme ve kabul edilme şeklinde bir sosyal desteğe ihtiyaç duyabilmektedirler. McGregor, vd. (2006) 
tarafından yapılan araştırmada, koruyucu ailelerin sosyal destek olarak kendileri gibi diğer koruyucu ailelerin fikirlerine ihtiyaç duydukları belirlenmiştir. Kendileriyle benzer süreçleri yaşayan ve benzer deneyimlere sahip olan ailelerin birbirlerini en iyi anlayan kişiler olması beklenen bir durumdur. Kurum tarafindan kendilerine verilecek desteğin; onları aile gruplarına ulaştırma, sosyal etkileşimi sağlama olabileceği önerisini getirmişlerdir (McGregor, vd., 2006). Ailelerin hem kendi yaşadıkları problemlerde yalnız olmadıklarını görmesi hem de bu problemleri nasıl aştıklarıyla ilgili deneyimlerini paylaşması oldukça önemlidir (Smyke, vd., 2009; Sinclair, Gibbs ve Wilson, 2004). Yaşadıkları deneyimlerin paylaşılmasının yanı sıra ailelerin koruyucu aile olarak devam etme kararını almalarında da sosyal destek önemli bir rol oynamaktadır (Geiger, vd., 2013).

Erken müdahale ve sosyal destek kanalları dışında, aileler, internet kaynaklarına başvurduklarını belirtmişlerdir. Ancak internette doğru bilgiye erişmek de bilinçli bir kullanıcı olmayı gerektirmektedir. Bu nedenle aileler doğru internet kaynaklarını kullanmaları için yönlendirmeye ihtiyaç duyabilmektedirler. Aile, Çalışma ve Sosyal Hizmetler Bakanlığının 2017 yılında yayınladığı belgede, internet yardım hattı da tanıtılmaktadır. Güvenli internet hizmetleri, internet ve mahremiyet, internette bilgi güvenliği gibi konularda destek vermeyi amaçlayan internet yardım hattı konusunda ailelerin bilgilendirilmesi gerekmektedir (AÇSHB, 2017). Böylece ailelerin doğru bilgiye erişimi için destek sağlanmış olacaktır.

Bu çalışmada evlat edinen ve koruyucu ailelerin; bebek ve küçük çocuklarıyla ilgili anlayışları, aralarındaki ilişkiyi nasıl tanımladıkları, bu dönemle ilgili merak ettikleri konuların neler olduğu, kendilerini hangi alanlarda yeterli ya da yetersiz hissettikleri ve yaşadıkları güçlükleri, bebeklik dönemiyle ilgili bilgileri öğrenme kanalları ve kendilerine verilecek bir eğitimde hangi konuların yer almasını istedikleri ortaya konulmuştur. Sonuç olarak;

- $\quad$ Evlat edinen ve koruyucu ailelerin yüceltilmiş çocuk anlayışıyla yetersiz çocuk anlayışı gibi farklı duyguları içeren bir bebeklik anlayışına sahip oldukları, ayrıca çocuklarını düşündüklerinde iç dünyalarında uyanan sorumluluk ya da mutluluk gibi duygularının olduğu görülmüştür.

- $\quad$ Ayrıca aileler çocuklarıyla aralarındaki ilişkiyi; hem sevgi, mutluluk, heyecan gibi güzel duygular hem de sorumluluk, yorgunluk, acemilik gibi zorlu duygular olarak tanımlamışlardır. Ailelerin ifadelerinden bu duyguların, ebeveynliğin ve etkileşimin bir yansıması olduğu sonucuna ulaşılmıştır.

- Bebeklik dönemiyle ilgili merak edilenler konusunda ise ailelerin; çocuklarının fizyolojik gereksinimleriyle (uyku, beslenme, gelişimsel özellikler, temel bakım) ve çocuk psikolojisiyle (evlat edinen ve koruyucu aile olma durumunun nasil ve ne zaman 
söylenmesi gerektiğini, bu aşamada ve ilerleyen dönemlerde sosyal çevrelerinin ne gibi etkileri olabileceğini) ilgili konuları öğrenmek istedikleri anlaşılmıştır.

- Yeterlilikler, yetersizlikler ve güçlükler konusunda evlat edinen ve koruyucu ailelerin kendilerini sevgi konusunda yeterli; inatlaşma/bebeği ikna etme, ağlama, uyku düzeni, doğru eğitim yöntemine karar verme ve istenmeyen davranışlar konusunda yapılabileceklerle ilgili yetersiz hissettikleri görülmüştür. Ayrıca, sosyal çevrede kabul sorunları ve çevre desteğini alamamayla ilgili de güçlük yaşadıkları ortaya çıkmışır.

- $\quad$ Evlat edinen ve koruyucu ailelerin bebekleri ve bebeklik dönemiyle ilgili bilgileri öğrendikleri kanalların; doktorlar, pedagoglar, kurumdaki uzmanlar, kişisel deneyimler, çocuğu olan ailelerin deneyimleri, aile büyüklerinin deneyimleri ve internet olduğu belirlenmiştir.

- $\quad$ Eğitimle ilgili öneriler bölümünde ailelerin; evlat edinilen/koruyucu aile bakımında olan çocuğa bu durumun açıklanması, çocuğun sosyal çevre tarafindan kabulü, güvenli bağlanmanın gerçekleşip gerçekleşmediği konularında eğitim almak istedikleri ve bu eğitimlerde çocukların gelişimsel dönemleriyle ilgili uzman desteği sağlanmasına yönelik istekleri ortaya konulmuştur. Bunun yanında ailelerin, kurumlarda çalışan meslek elemanlarının hizmet içi eğitimler alması gerektiği ve ilgili bakanlıklarla iş birliğinin gerekliliği düşüncesinde oldukları görülmüştür.

Evlat edinen ve koruyucu aile olan ebeveynlerin bebek ve küçük çocuklarıyla ilgili eğitim ihtiyaçları 1şığında bu çalışma;

- $\quad$ Evlat edinen ve koruyucu ailelerin çocuk gelişimi ve eğitimi, toplumsal destek ve genel olarak anne/babalıkla ilgili konulardaki ihtiyaçlarını ülke genelinde ortaya koymaya yönelik nicel çalışmalar yapılabilir.

- $\quad$ Evlat edinen ve koruyucu ailelerle birlikte biyolojik ailelerin de yer aldığı karşılaştırmalı araştırmalar arttırılabilir.

Uygulamalara yönelik;

- Ailelerin kendilerini yetersiz hissettikleri ya da güçlük yaşadıkları konularda desteklenmelerine yönelik erken müdahale programları hazırlanabilir ve bu programların daha çok aileye ulaşabilmesi için sürdürülebilirliği sağlanabilir.

- $\quad$ Evlat edinen ve koruyucu ailelerin daha çok evlat edinen ve koruyucu aileyle buluşması sağlanarak deneyimlerini paylaşmaları (sosyal destek grupları)sağlanabilir. 
- $\quad$ Aileler, çocuk gelişimiyle ilgili doğru ve sağlıklı bilgi alabilecekleri kanallar konusunda bilgilendirilebilir.

- Çocuklarla çalışan tüm meslek gruplarının; koruma altındaki çocuklar, evlat edinen çocuklar ve koruyucu aile bakımında olan çocuklarla ilgili konularda aldıkları hizmet içi eğitimler artırılabilir.

- Evlat edinen/koruyucu ailelerle çalışan meslek elemanlarının yanı sıra çocuklarla çalışan bütün profesyonellerin işbirliği yapmaları sağlanabilir.

\section{KAYNAKÇA}

Abukan, B. (2020). Çocukluk çağı travmalarının koruyucu aile içinde sağaltımı üzerine bir değerlendirme. Journal of Society \& Social Work, 31(1), 241-260.

Aile, Çalışma ve Sosyal Hizmetler Bakanlığı (AÇSHB), (2017). "Türkizye'de çocuklara yönelik koruyucu ve önleyici politikalar değerlendirme çalıstayı raporu”, 27 Temmuz 2017 Crowne Plaza, Ankara.

Ainsworth, M. D. S., Blehar, M., Waters, E., \& Wall, S. (1978). Patterns of attachment. A psychological study of the strange situation. Classic edition. New York and London: Routledge.

Altınoğlu-Dikmeer, İ., Erol, N., \& Gençöz, T. (2014). Evlat edinilmiş ve biyolojik ebeveyniyle yaşayan çocukların davranışsal ve duygusal sorunları ve bağlanma düzeyleri ile anne babalarının çocuk yetiştirme stillerinin karşılaştırmalı olarak değerlendirilmesi. Türk Psikiyatri Dergisi, 25(4), 234-243.

Avcı, N. (2019). Cocuk Katıllmı ders notlar, Gazi Üniversitesi Eğitim Bilimleri Enstitüsü, Çocuk Gelişimi ve Eğitimi Doktora Programı, Çocukluk Anlayışı ve Çocuk Katılımı: Tüm Çocuklara Hizmet Etme, Ankara.

Avcı, N., \& Pekince, P. (2018). Çocukların çocukluğa bakış açıları. Eğitim ve Bilim, 43(196), 1-25.

Avc1, N., Kara, C., Ayhan, S., Güngör, N. \& Kayac1k, K. (2014), Investigation of prospective teachers' understanding of childhood. Erpa Congress, 6-8 June 2014, İstanbul. Procedia Social and Behavioral Sciences.

Avc1, Ü. E. (2019). Evlat edinen, koruyucu annelik yapan ve biyolojik anne olan kadinlarn annelike ile ilgili görüslerinin incelenmesi, (Yüksek Lisans Tezi). Ankara Yıldırım Beyazıt Üniversitesi, Ankara.

Balasar, G. (2019). Yetişkinlerin çocukluğa bakıısı: Ankara ili örneği. (Yüksek Lisans Tezi). Gazi Üniversitesi, Ankara.

Batman, D. (2018). Gebe kadınların gebelikleriyle ilgili araştırdığı konular ve bilgi kaynakları: nitel bir çalışma. Kocaeli Üniversitesi Sağhle Bilimleri Dergisi, 4(3), 63-69.

Baysal, A.E. (2017). Koruyucu aile uygulamalar ve sonucları: İstanbul örneği. (Yayımlanmamış Yüksek Lisans Tezi). İstanbul Sabahattin Zaim Üniversitesi, İstanbul.

Berk, L. E. (2013). Bebekler ve çocuklar. (N. Işıkoğlu Erdoğan, çev.). Ankara: Nobel. 
Birleşmiş Milletler Çocuk Hakları Komitesi, (2009). Cocuk haklarna dair sözleşme genel yorum no: 12 socuğun dinlenilme bakekr. Elli Birinci Oturum, Cenevre.

Bowlby, J. (2012a). Bağlanma. (T. V. Soylu, çev.). İstanbul: Pinhan.

Bowlby, J. (2012b). Güvenli bir dayanak: Ebeveyn-çocuk bağlanması ve sağllkh insan gelişimi (S. Güneri, çev.). İstanbul: Psikoterapi Enstitüsü.

Boyd Webb, N. (2017). Cocuklarla sosyal hizmet uygulaması. (E. Erbay, cev. ed.). Ankara: Nika.

Chakawa, A., Frye, W., Travis, J., \& Brestan-Knight, E. (2020). Parent-child interaction therapy: Tailoring treatment to meet the sociocultural needs of an adoptive foster child and family. Joumal of Family Social Work, 23(1), 53-70.

Chanmugam, A., Madden, E. E., Hanna, M. D., Cody, P. A., Ayers-Lopez, S. J., McRoy, R. G., \& Ledesma, K. J. (2017). Agency-related barriers experienced by families seeking to adopt from foster care. Adoption Quarterly, 20(1), 25-43.

Chlup, D. T., \& Collins, T. E. (2010). Breaking the ice: using ice-breakers and re-energizers with adult learners. Adult Learning, 21(3-4), 34-39.

Christensen, L. B., Johnson, R. B., \& Turner, L. A. (2015). Arasttrma yöntemleri desen ve analiæ: (A. Aypay, çev. ed.). Ankara: Anı.

Creswell, J. W. (2014). Araștırma deseni, nitel, nicel ve karma yöntem yaklaşımları. (S. B. Demir, çev.). Ankara: Eğiten Kitap.

Daniel, E. (2011). Gentle iron will: Foster parents' perspectives. Children and Youth Services Review, 33(6), 910-917.

Deci, E. L. \& Ryan, R. M. (2000). The "what" and "why" of goal pursuits: Human needs and the self-determination of behavior. Psychological Inquiry, 11(4), 227-268.

Dichtelmiller, M., Meisels, S. J., Plunkett, J. W., Bozytnski, M. E. A., Claflin, C., \& Mangelsdorf, S. C. (1992). The relationship of parental knowledge to the development of extremely low birth weight infants. Journal of Early Intervention, 16(3), 210-220.

Emre-Bolatbaş, D. \& Yıldız-Bıçakçı, M. (2018). Çocuk gelişimini değerlendirmede biçimsel olmayan yöntemler (Standardize olmayan yöntemler). (P. Bayhan, Ed.), Gelisimsel Değerlendirme içinde (s. 103-135). Ankara: Hedef.

Erdugan, S. (2019). Koruyucu aile modelinde aile yassam deneyimleri: Aile sistemleri teorisi temelinde niteliksel bir arastırma, Hacettepe Üniversitesi, Ankara.

Erkan, S. (2013). Aile ve aile eğitimi ile ilgili temel kavramlar. F. Temel (Ed.), Aile eğitimi ve erken çocukluk eğitiminde aile katılım çalısmalar içinde (s. 3-21). Ankara: Anı.

Ertem, I. O., Atay, G., Dogan, D. G., Bayhan, A., Bingoler, B. E., Gok, C. G., ... \& Isikli, S. (2007). Mothers' knowledge of young child development in a developing country. Child: care, bealth and development, 33(6), 728-737. 
Geiger, J. M., Hayes, M. J., \& Lietz, C. A. (2013). Should I stay or should I go? A mixed methods study examining the factors influencing foster parents' decisions to continue or discontinue providing foster care. Children and Youth Services Review, 35(9), 1356-1365.

Geiger, J. M., Piel, M. H., Lietz, C. A., \& Julien-Chinn, F. J. (2016). Empathy as an essential foundation to successful foster parenting. Journal of Child and Family Studies, 25(12), 37713779 .

Gelkopf, M., \& Jabotaro, S. E. (2013). Parenting style, competence, social network and attachment in mothers with mental illness. Child \& Family Social Work, 18(4), 496-503.

Glascoe, F. P., \& Dworkin, P. H. (1995). The role of parents in the detection of developmental and behavioral problems. Pediatrics, 95(6), 829-836.

Glesne, C. (2015). Nitel araştırmaya giriş. (A. Ersoy \& P. Yalçınoğulu, çev.). Ankara: Anı.

Goodnow, J. J. (1988). Parents' ideas, actions, and feelings: Models and methods from developmental and social psychology. Child development, 286-320.

Gopnik, A. (2015). Filorof bebek (O. Tuncay, çev.). İstanbul: Gün.

Gökce, H. (2017). Bir sosyal politika olarak evlât edindirmenin toplumsal direnç kaynakları. Uluslararası Beşeri ve Sosyal Bilimler Inceleme Dergisi, 1(1), 19-38.

Greenspan, S. I. \& Lewis, N. B. (2006). Bebeklerde ve çocuklarda sağhlkhl rubsal gelişim. (İ. Ersevim, çev.). İstanbul: Özgür.

Hacıhasanoğlu-Aşılar, R., \& Bekar, P. (2018). 0-24 aylık çocuğu olan annelerin çocuk bakımına ilişkin bilgi, geleneksel inanç ve uygulamaları. Güncel Pediatri, 16(2), 1.

Haring, U., Sorin, R., \& Caltabiano, N. J. (2019). Reflecting on childhood and child agency in history. Palgrave Communications, 5(1), 1-9.

Hayes, M. J., Geiger, J. M., \& Lietz, C. A. (2015). Navigating a complicated system of care: Foster parent satisfaction with behavioral and medical health services. Child and Adolescent Social Work Journal, 32(6), 493-505.

İstikbal, E. N. (2020). Anne çocuk ilişkilerinin nesiller arast aktarmmmn annelerin anlatılar üzerinden niteliksel yöntemle araștırlması. (Yüksek Lisans tezi). Maltepe Üniversitesi, İstanbul.

James, A. (2010). Interdisciplinarity-for better or worse. Children's Geographies, 8(2), 215-216.

James, A. L. (2010). Competition or integration? The next step in childhood studies?. Childhood, 17(4), 485-499.

Jenks, C. (2005). Childhood (2nd ed.). London: Routledge.

Johnson, B. \& Christensen, L. (2014). Eğitim araştırmalar. Nicel, nitel ve karma yaklaşımlar. (S. B. Demir, çev. ed.). Ankara: Eğiten Kitap.

Joussemet, M., Landry, R., \& Koestner, R. (2008). A self-determination theory perspective on parenting. Canadian Psychology/Psychologie canadienne, 49(3), 194. 
Julien-Chinn, F. J., Cotter, K. L., Piel, M. H., Geiger, J. M., \& Lietz, C. A. (2017). Examining risk, strengths, and functioning of foster families: Implications for strengths-based practice. Journal of Family Social Work, 20(4), 306-321.

Kahraman, S., Kabalcıoğlu, F., \& Ersin, F. (2016). Şanlıurfa'daki gebelerin bebek bakımına ilişkin bilgi düzeyleri. Sosyal Politika Callşmalar Dergisi, 36, 79-97.

Karaaslan, T. (2016). Gelişimin değerlendirilmesi, izlenmesi ve desteklenmesinde klinik ve iletişim beceri eğitimi neden gereklidir?. Inönü Üniversitesi Sağhlk Hiæmetleri Meslek Yüksek Okulu Dergisi, 4(2), 17-31.

Karataş, K. (2007). Türkiye'de çocuk koruma sistemi ve koruyucu aile uygulamaları üzerine bir değerlendirme. Toplum ve sosyal Hizmet, 18(2), 7-20.

Kilanowski, J. F. (2012). Breaking the Ice: A Pre-intervention Strategy to Engage Research Participants. J Pediatr Health Care. 26(3), 209-212.

Kunt-Bulut, M. (2015). Okul öncesi ögretmenlerinin çocukluk anlayışı. (Yüksek Lisans Tezi), Gazi Üniversitesi, Ankara.

Kunt-Bulut, M., \& Avc1, N. (2016). Çocukluk: Sanal ortamlarda çocukluğa bakış. Kastamonu Education Journal, 24(5), 23-35.

LaBrenz, C. A., Fong, R., Brown, K., \& Findley, E. (2020). Adoptive Families' Views about Effective Services Prior to Residential Treatment Center Placement. Adoption Quarterly, 23(3), 219-241.

Lietz, C. A., \& Strength, M. (2011). Stories of successful reunification: A narrative study of family resilience in child welfare. Families in society, 92(2), 203-210.

MacGregor, T. E., Rodger, S., Cummings, A. L., \& Leschied, A. W. (2006). The needs of foster parents: A qualitative study of motivation, support, and retention. Qualitative social work, 5(3), 351-368.

Mallette, J. K., Almond, L., \& Leonard, H. (2020). Fostering healthy families: An exploration of the informal and formal support needs of foster caregivers. Children and Youth Services Review, 110, 104760.

Martin, B., Kelly, M. M., \& Towner-Thyrum, E. (1999). Adoptive family adjustment and its relation to perceived family environment. Adoption Quarterly, 3(1), 49-60.

Masterson, J. (2013). Bağlanma kuramı ve nörobiyolojik kendilik gelişimi açısından kişilik bozuklukları: klinik bir bütünleştirme. F., Özakkaş, T., \& Çorak, A. (Eds.). İstanbul: Litera.

Merriam, S. (2015). Nitel araştırma. Desen ve uygulama için bir rehber. (S. Turan, çev. ed.). Ankara: Nobel.

Miles, M. B. \& Huberman, A. M. (2015). Nitel veri analiæi (S. Akbaba Akgül ve A. Ersoy, çev.). Ankara: Pegem Akademi.

Miller, S. A. (1988) Parents' beliefs about children's cognitive development. Child Development, 59, 259-285. 
Miller-Ott, A. E. (2017). Developing and maintaining foster family identity through foster parents' identity work. Journal of Family Communication, 17(3), 208-222.

Montigny, F. \& Lacharite,C. (2004). Fathers' perceptions of the immediate postpartal period. Journal Of Obstetric Gynecologic And Neonatal Nursing. 33(3), 328-339.

Neuman, W. L. (2010). Toplumsal araştırma yöntemleri. Nitel ve nicel yaklaşımlar. (S. Özge, çev.). İstanbul: Yayınodas1.

Nowak-Fabrykowski, K., Helinski, M., \& Buchstein, F. (2009). Reflection of foster parents on caring for foster and adopted children and their suggestions to teachers. Early Child Development and Care, 179(7), 879-887.

Özbesler, C. (2009), Koruyucu aile hizmetlerinde değerlendirme süreci. Aile ve Toplum, 4(16), 8694.

Patton, M. Q. (2014). Nitel araştırma ve değerlendirme yöntemleri. (M. Bütün ve S. B. Demir, çev. ed.). Ankara: Pegem Akademi.

Pekince, P., \& Avci, N. (2018). Children's Perspective on the Right of Self-determination. International Electronic Journal of Elementary Education, 10(4), 431-439.

Perry, B. \& Szalavitz, M. (2017). Köpek gibi büyütülmüss çocuk. (E. Söğüt, çev.). İstanbul: Okuyanus.

Pınar, G., Doğan, N., Algier, L., Kaya, N., \& Çakmak, F. (2009). Annelerin doğum sonu konforunu etkileyen faktörler. Dicle T⿰р Dergisi, 36(3), 184-190.

Piel, M. H., Geiger, J. M., Julien-Chinn, F. J., \& Lietz, C. A. (2017). An ecological systems approach to understanding social support in foster family resilience. Child \& Family Social Work, 22(2), 1034-1043.

Prout, A. (2011). Taking a step away from modernity: Reconsidering the new sociology of childhood. Global studies of childhood, 1(1), 4-14.

Ross, L., Holliman, D., \& Dixon, D. R. (2003). Resiliency in family caregivers: Implications for social work practice. Journal of Gerontological Social Work, 40(3), 81-96.

Ryan, K. W. (2012). The new wave of childhood studies: Breaking the grip of bio-social dualism?. Childhood, 19(4), 439-452.

Santrock, J. W. (2015). Yaşam boyu gelişim: Gelişim psikolojisi (G. Yüksel, çev.). Ankara: Nobel.

Sari, T. (2014). Öznelik Kapasitesi Bağlamında Biyolojik Annelik: Üremeye Yardımcı Teknolojileri Kullanan Kadinlarn Deneyimleri. (Yüksek Lisans Tezi). Adnan Menderes Üniversitesi, Aydın.

Shklarski, L. (2019). Foster parent skills and dilemmas: A qualitative study. Child Welfare, 97(2), 41 62.

Sinclair, I., Gibbs, I., \& Wilson, K. (2004). Foster Carers: Why they stay and why they leave. Jessica Kingsley Publishers. 
Smyke, A. T., Zeanah, C. H., Fox, N. A., \& Nelson, C. A. (2009). A new model of foster care for young children: the Bucharest early intervention project. Child and Adolescent Psychiatric Clinics, 18(3), 721-734.

Sorin, R. (2005) Changing Images of Childhood- Reconceptualising Early Childhood Practice. International Journal of Transitions in Childhood, 1, 12-21.

Şahinöz, A. \& Bütün-Ayhan, A. (2020). Annelerin Bebeklik Döneminde Gelişime İlişkin Bilgi ve Kayg1 Düzeylerinin Değerlendirilmesi. Türkiye Çocuk Hastallklar Dergisi, 14(3), 249-257.

Tan, M. (1989). Çağlar Boyu Çocukluk. Ankara Üniversitesi Eğitim Bilimleri Fakülttesi Dergisi, 23(2), 71-88.

Tezel, Z., Demirel, B., \& Şahin Kaya, Z. (2018). Ailelerin Koruyucu Aile Olmaya Karar Vermelerinde Etkili Olan Etmenler ile Koruyucu Aile Olmanın Anlam ve Önemi. Muğla Sitkr Kocman University Journal of Social Sciences, 43.

Trawick-Swith, J. (2013). Erkeen çocukluk döneminde gelişim: Çok kültürlü bir bakış açısı. Ankara: Nobel.

Van Den Dries, L., Juffer, F., Van Ijzendoorn, M. H., \& Bakermans-Kranenburg, M. J. (2010). Infants' physical and cognitive development after international adoption from foster care or institutions in China. Journal of Developmental \& Behavioral Pediatrics, 31(2), 144-150.

Van der Kolk, B. A. (2020). Beden kaynt tutar. Travmann iyileşmesinde beyin, zibin, beden. (C. Maral, çev.). Ankara: Nobel Yaşam.

Wright, L. E. (2001). Toolbox No. 1: Using Visitation To Support Permanency. Toolboxes for Permanency. Child Welfare League of America. Washington DC.

Yıldırımalp, S., \& Hız, Ö. (2020). Koruyucu ailelerin sorunları Denizli ili örneği. Ömer Halisdemir Üniversitesi İktisadi ve İdari Bilimler Fakültesi Dergisi, 13(2), 185-202.

Yin, R. K. (2017). Durum çalışması araştırması uygulamaları. (İ. Günbayı, çev.). Ankara: Nobel. 